Research Article

\title{
Shear Behavior of Corrugated Steel Webs in H Shape Bridge Girders
}

\author{
Qi Cao, ${ }^{1}$ Haibo Jiang, ${ }^{2}$ and Haohan Wang ${ }^{2}$ \\ ${ }^{1}$ State Key Laboratory of Coastal and Offshore Engineering, Dalian University of Technology, Dalian 116024, China \\ ${ }^{2}$ School of Civil and Transportation Engineering, Guangdong University of Technology, Guangzhou 510006, China \\ Correspondence should be addressed to Haibo Jiang; hbjiang@gdut.edu.cn
}

Received 29 January 2015; Accepted 16 March 2015

Academic Editor: George Tsiatas

Copyright (c) 2015 Qi Cao et al. This is an open access article distributed under the Creative Commons Attribution License, which permits unrestricted use, distribution, and reproduction in any medium, provided the original work is properly cited.

\begin{abstract}
In bridge engineering, girders with corrugated steel webs have shown good mechanical properties. With the promotion of composite bridge with corrugated steel webs, in particular steel-concrete composite girder bridge with corrugated steel webs, it is necessary to study the shear performance and buckling of the corrugated webs. In this research, by conducting experiment incorporated with finite element analysis, the stability of $\mathrm{H}$ shape beam welded with corrugated webs was tested and three failure modes were observed. Structural data including load-deflection, load-strain, and shear capacity of tested beam specimens were collected and compared with FEM analytical results by ANSYS software. The effects of web thickness, corrugation, and stiffening on shear capacity of corrugated webs were further discussed.
\end{abstract}

\section{Introduction}

The corrugated steel web girder bridges have begun to be built since 1980s in France and Japan and have been gaining increasingly interest and implementation since then. The original flat steel plates were manufactured to corrugated shape and used as webs in bridge girders. By using corrugated steel webs, the thickness of the web could be reduced and reinforcement of stiffener can be avoided, resulting in economical benefits and life span improvement.

Compared with prestressed concrete girders, at the same cross section layout, by using corrugated steel web box girder, it can reduce the weight of web and greatly improve the efficiency of the prestressing and material utilization since webs are under pure shear state while flanges are under flexural deformation $[1,2]$. Compared to traditional flat steel plate webs, it is also a competitive way to use corrugated steel webs in girder bridges because it provides lateral restraint and stability to the girders and reduces stiffening welding process as well as construction time [3].

Research in corrugated web girder bridges has been primarily focused on buckling analysis of webs. Li and Guo [2] considered the effects of initial geometric imperfection and used ANSYS to analyze the corrugated steel web beams. The results showed that the shear capacity of corrugated steel web was superior to ordinary steel I-beam. Abbas et al. [4] proposed practical calculation equation for buckling strength of the corrugated steel web and conducted FEM analysis to compare the results with the theoretical results for validation. Gil et al. [3] studied effects of various parameters on buckling strength and put forward a formula for buckling strength design suitable for three buckling modes. Through investigation, Song et al. [5] found that, with the increase of height of corrugation, it tended to change from whole buckling to local buckling mode. Also, shear capacity resulted from buckling increases as web thickness increases. Zhou et al. [6] discussed the instability mechanism of corrugated steel web by experimental investigation and proposed coefficient values used for whole buckling mode of webs. It provided theoretical basis for design and calculation of the thickness of corrugated web. It was summarized in [7] that there are three types of shear buckling in trapezoid corrugated webs including local buckling, global buckling, and interactive buckling. It was also proposed to combine the buckling calculation equation on the basis of theoretical analysis and parameter study. In addition, the accuracy of proposed formula was discussed and compared with experimental data. It was reported in the study by Moon et al. [8] that the buckling strength of I-girder 

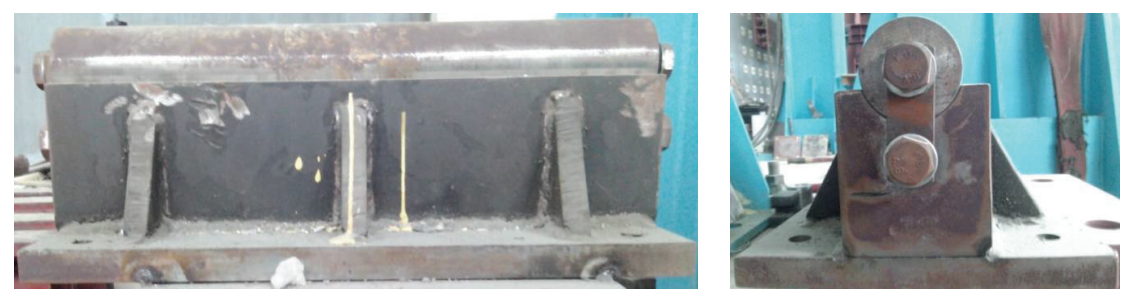

FIGURE 1: Experimental supports.

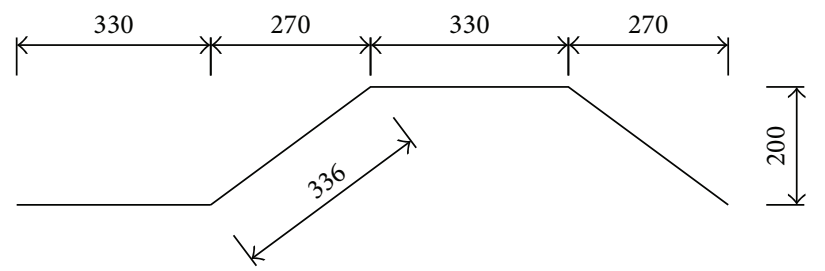

FIGURE 2: Schematic view of Type 1200 corrugated shape (unit: mm).

\begin{tabular}{|l||l||l|l|}
\hline & Stiffener & Slain webs & Stiffener \\
\hline & & & \\
\hline
\end{tabular}

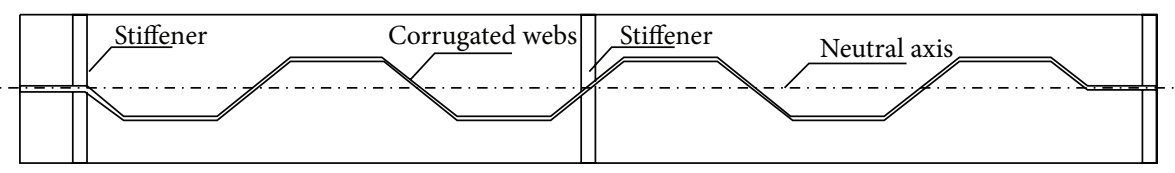

Figure 3: Layout of web and stiffener.

with corrugation could be increased to maximum 10\% with increasing corrugation angle.

Despite that the parameters effect and design equations have been studied in corrugated steel web girder bridges, experimental studies regarding shear buckling and failure modes as well as the comparison between FEM and experiment are quite limited.

\section{Experimental Program}

2.1. Specimen Design. It is necessary to design specimen size according to the testing instrument in order to make sure that specimens can be tested on the loading platform. Loading platform is square shaped with a size of $1200 \mathrm{~mm} \times 1200 \mathrm{~mm}$. The bearings are shown in Figure 1, in which the base plate size is $500 \mathrm{~mm} \times 230 \mathrm{~mm}$.

According to the hot rolled $\mathrm{H}$ shaped steel and cut $\mathrm{T}$ section steel [9], the narrow flange shape steel has good flexural bearing capacity. Flange width is $150 \mathrm{~mm}$ and the height to width ratio of $\mathrm{HN}$ series in $\mathrm{H}$ shaped steel is $1: 2$ to $1: 3.3$. Welding H-type steel section height of $350 \mathrm{~mm}$ is used. Continuous dihedral angle seam welding was adopted in this study. Type 1200 corrugated steel shape was used according to shear folding processing requirements as shown in Figure 2. The corrugated web scale ratio of 1:5 was determined and thickness of web was chosen as $2 \mathrm{~mm}$ and $3 \mathrm{~mm}$.
Supporting stiffener in the specimen support is arranged in pairs. According to specimen design, ultimate bearing capacity of steel beams is expected to be $310 \mathrm{KN}$ and the minimum thickness of stiffener $t=9.6 \mathrm{~mm}$ which is rounded up to $t=10 \mathrm{~mm}$. The layout of web and stiffener is shown in Figure 3. Three wavelengths were designed along the longitudinal beam layout. The ripples in the beam at the loading point were set on the longitudinal axis and no ripple is designed at supports. Transverse stiffener was arranged symmetrically on both sides of web as shown in Figure 3.

The flexural capacity of corrugated web steel girder specimen is provided by the upper and lower flanges theoretically. In order to increase its flexural capacity, supporting stiffeners were used as shown in Figure 4. From Figures 3 and 4, according to the design, the thicknesses of stiffeners 1,2, and 3 are all $10 \mathrm{~mm}$, with three wavelengths of $720 \mathrm{~mm}$. Specimen total longitudinal length $L=816 \mathrm{~mm}$ and the effective length $l=768 \mathrm{~mm}$. Elevation view and cross section views at end at bearing are shown in Figure 5. The corrugated webs and plain webs in $\mathrm{H}$ shape steel girder are shown, respectively, in Figures 5(a) and 5(b).

2.2. Specimen Fabrication. Five welded $\mathrm{H}$ shape steel girder specimens were fabricated in a factory as shown in Figure 6. The parameters of steel materials that were used as the web, stiffener, and flange are listed in Table 1 . Shear folding process was chosen to manufacture corrugated shape web from $2 \mathrm{~mm}$ 


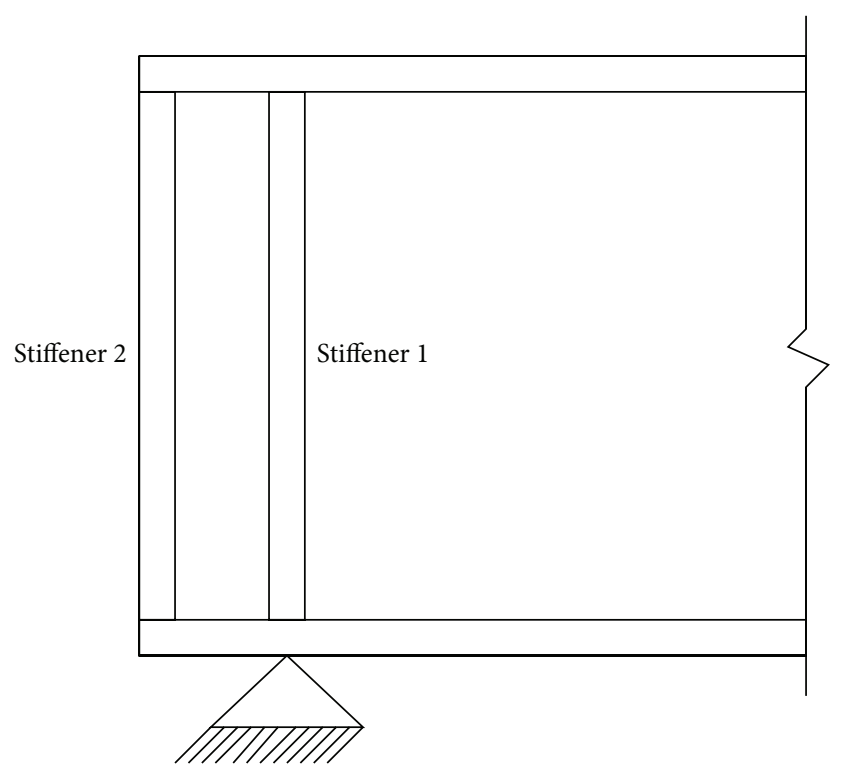

(a) Left end

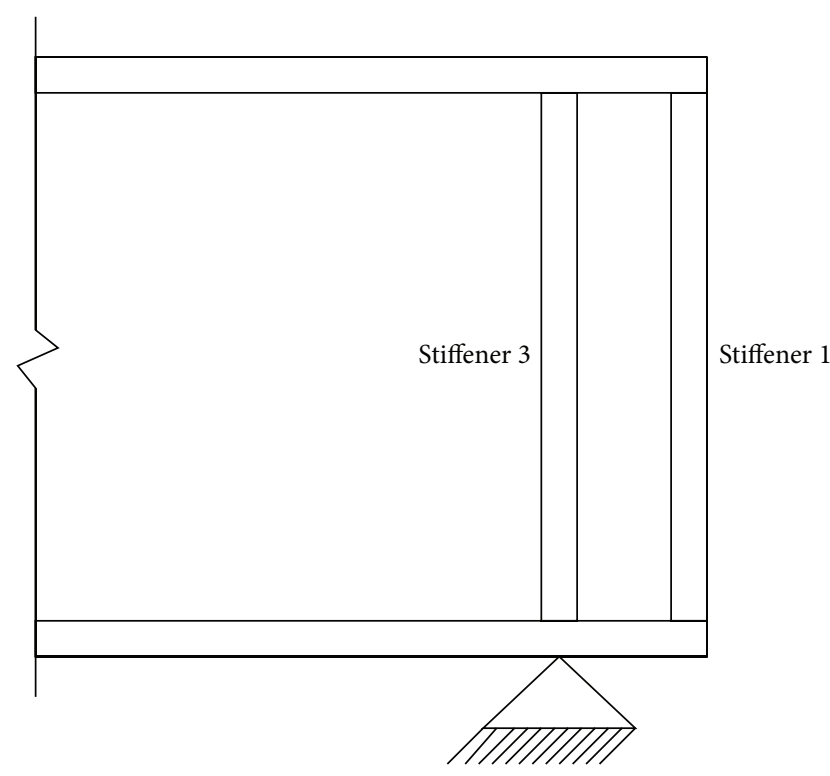

(b) Right end

FIGURE 4: Details of specimen ends with stiffeners.
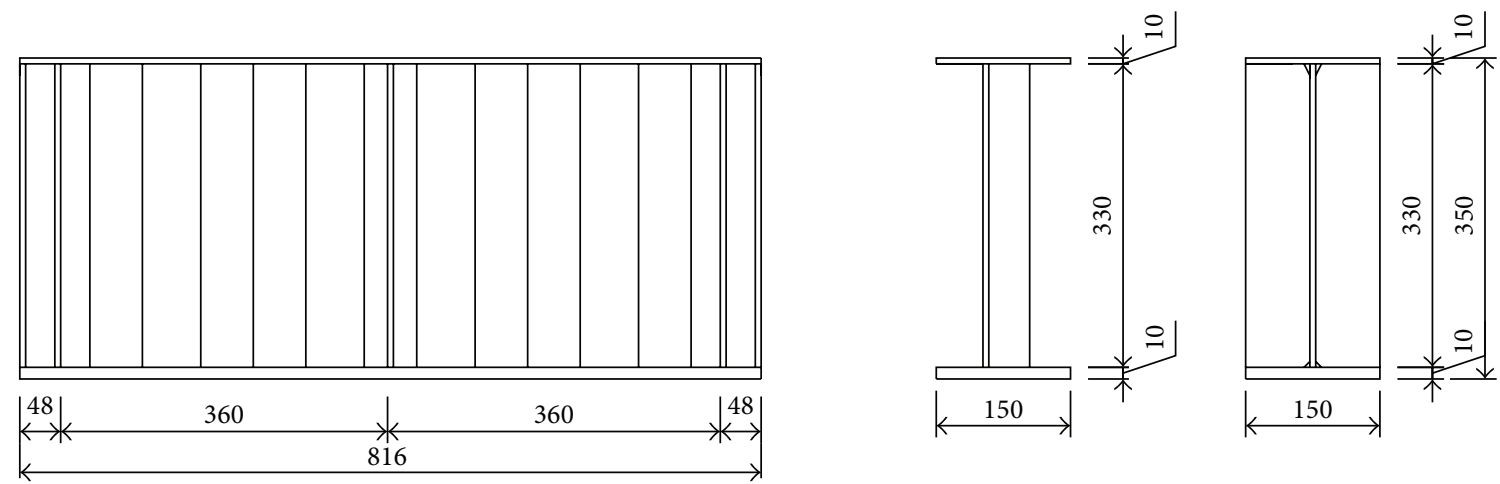

(a) Corrugated web
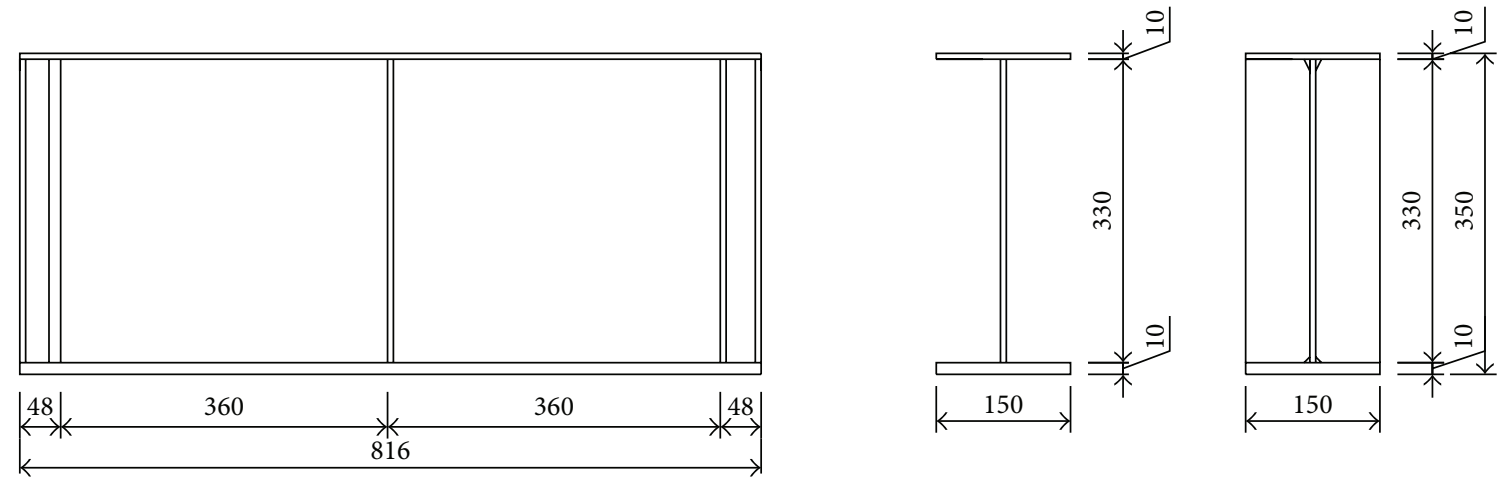

(b) Plain web

Figure 5: Elevation and cross section views of $\mathrm{H}$ shape steel girder (unit: $\mathrm{mm}$ ).

and $3 \mathrm{~mm}$ steel plate. The shear folding process is shown in Figure 7. A complete wavelength of ripples can be formed after four punching shearing processes.

The rust was removed by using manual grinding machine especially in the welding fillet between web and flange area to prevent strength reduction. The specimen after derusting is shown in Figure 6(b). Corrugated size and shape are shown in Table 1 and Figure 8.

To control the manufacturing error of eccentricity between web and centerline of flange, semiautomatic gas 
TABLE 1: The characteristic parameters of specimen (Unit: $\mathrm{mm}$ ).

\begin{tabular}{lccccccccc}
\hline \multirow{2}{*}{ Label } & \multirow{2}{*}{ Specimen length } & \multicolumn{3}{c}{ Web } & \multicolumn{3}{c}{ Ripple parameters } & \multirow{2}{*}{ Ripple type } & \multirow{2}{*}{ Stiffener type } \\
& & Height & Thickness & $a$ & $b$ & $c$ & $d$ & Trapezoid \\
C3F & 816 & 330 & 3 & 66 & 54 & 66 & 40 & Full \\
C3H & 816 & 330 & 3 & 66 & 54 & 66 & 40 & Trapezoid \\
C2F & 816 & 330 & 2 & 66 & 54 & 66 & 40 & Trapezoid & Falf \\
C2H & 816 & 330 & 2 & 66 & 54 & 66 & 40 & Trapezoid & Half \\
P3F & 816 & 330 & 3 & & & - & & None \\
\hline
\end{tabular}

Note: $\mathrm{C}$ and $\mathrm{P}$ represent corrugated steel webs and plain steel webs, respectively; 3 and 2 represent $3 \mathrm{~mm}$ and $2 \mathrm{~mm}$ thick webs, respectively; $\mathrm{F}$ and $\mathrm{H}$ represent types of stiffener which are full stiffener restraint and half stiffener restraint, respectively.

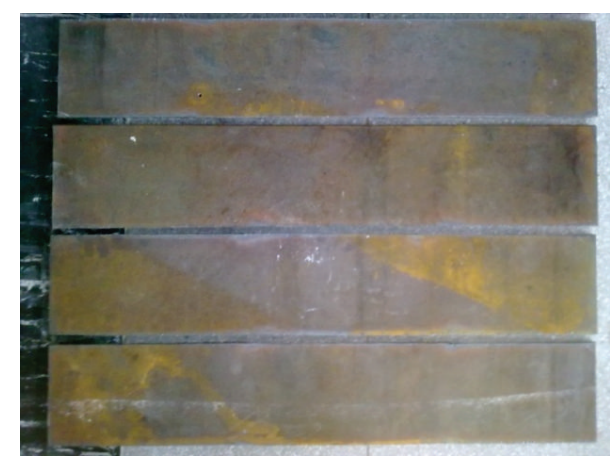

(a) Cutting

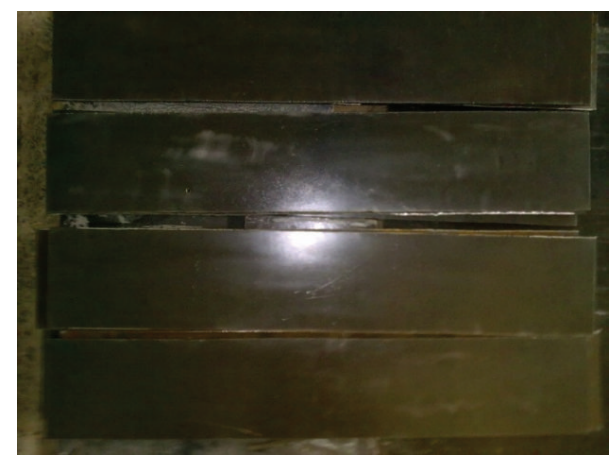

(b) Rust removal

Figure 6: Steel raw materials.
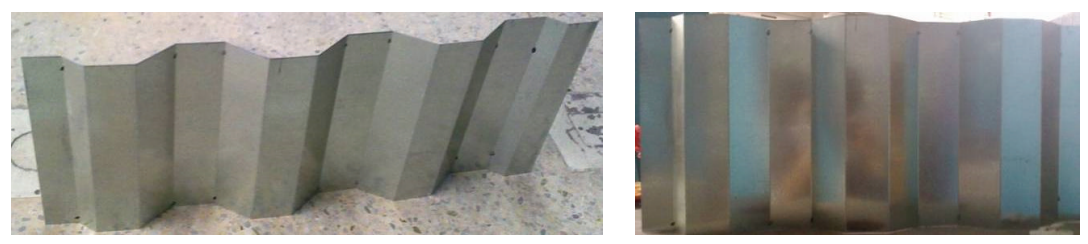

FIGURE 7: Corrugated webs after shear forming.

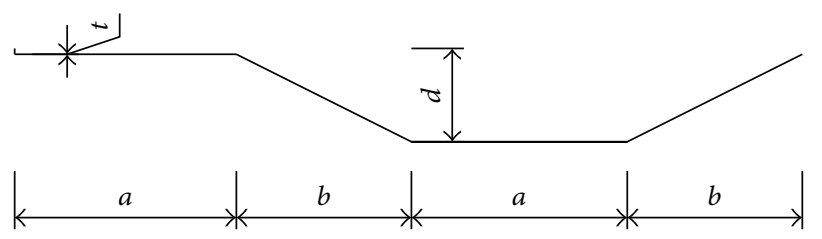

FIGURE 8: Corrugation profiles of specimen.

shielded welding seams were adopted as the welding procedure. As a result, ER50 type welding wire and $5 \mathrm{~mm}$ leg size in fillet weld leg is used to avoid shrinkage in welding line during the cooling process. The welded girder specimens are shown in Figure 9.

2.3. Material Properties. In order to test the mechanical properties of the steel materials, yield strength, elongation and poisson's ratio, and elastic modulus were tested in accordance with Chinese testing standards. Mechanical properties specimens were sampled by using plasma cutting from corrugated steel girder specimens. The sampling positions are at web, flange, and the stiffener. Three groups of specimens were taken according to the thickness of the steel $a=2 \mathrm{~mm}, 3 \mathrm{~mm}$, and $10 \mathrm{~mm}$. The coefficient $k$ was taken as 5.65 for scaled specimens. The sample size with dimensions as well as photos of specimens is shown in Figure 10. DDL100 electronic universal testing machine was used to conduct the tensile property test, as shown in Figure 11.

All specimens showed "necking" after strain hardening as shown in Figure 12(d). Specimens with $2 \mathrm{~mm}$ and $3 \mathrm{~mm}$ thickness showed $45^{\circ}$ fracture failure, presented in Figures 12(a), 12(b), 12(c), and 12(f). In addition, $10 \mathrm{~mm}$ thickness specimen presented zigzag shape fracture failure as shown in Figures 12(e) and 12(g). The tested properties of tensile coupons are shown in Table 2. The values in Table 2 were used as reference data for the material constitutive relation in FE analysis. 

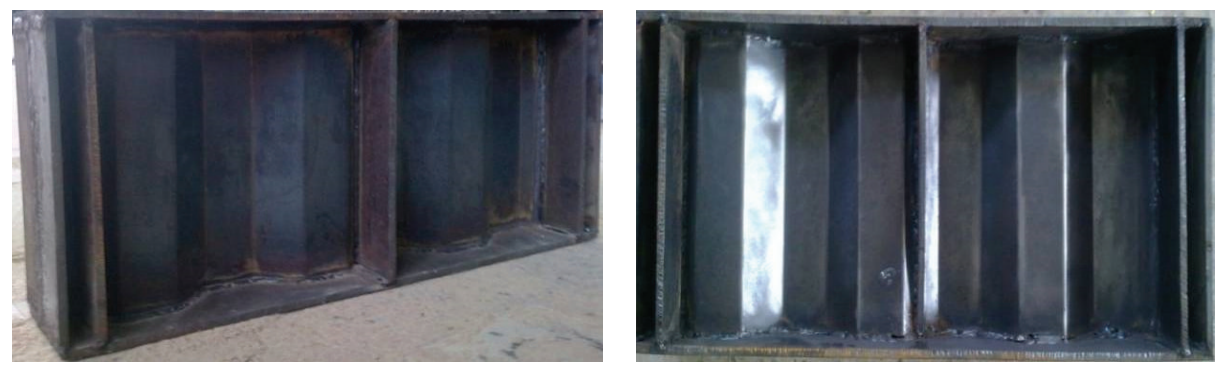

Figure 9: Diagram of specimen.
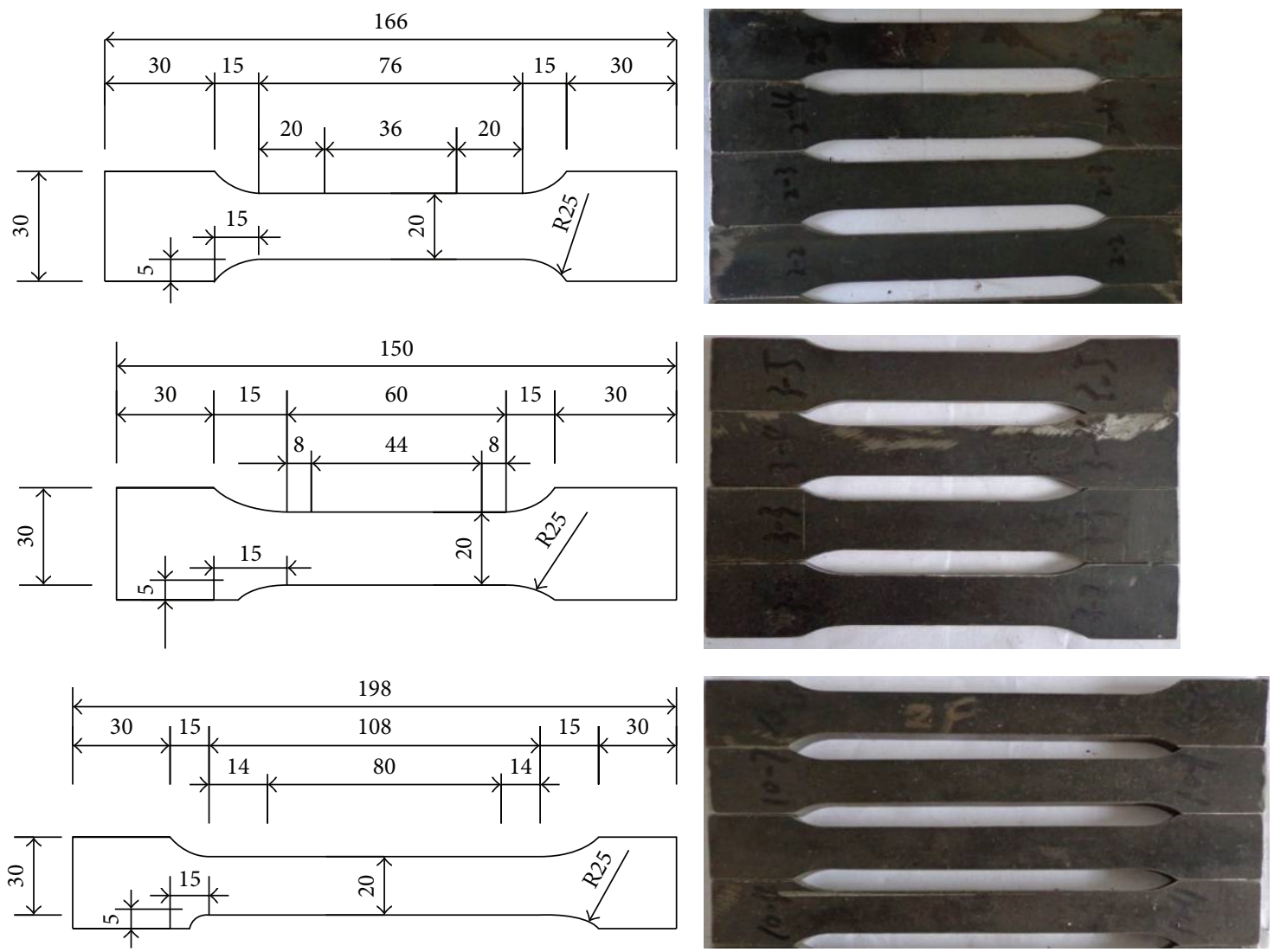

FIgURE 10: Configuration and photos of tensile specimens.

2.4. Test Setup. Three-point bending test was conducted on corrugated web specimens. Two simple supports were placed on both ends with one single point load in the middle. Test setup is shown in Figure 13. Strain gages and linear variable displacement transducers (LVDT) were attached on the specimen to collect strain and displacement data during the test. The data were collected by TDS-530 static DAQ testing system. Figure 14 shows the elevation view and labeling of web plates.

\section{Results and Discussions}

3.1. Failure Modes. Two different buckling modes consisting of local and global buckling were observed in the test. Local buckling is defined as follows: at a certain load, a single folded plate forms a buckling but does not spread to adjacent folded plate. On the other hand, under a specified load, if buckling was formed in more than one corrugated plate, it is considered as the global buckling.

Almost all of the buckling in the test was local buckling except for specimen P3F. However, it should be noted that the local buckling is almost always followed by the global buckling especially for the $2 \mathrm{~mm}$ thickness welding corrugated webs specimens. Three different failure modes were observed in the test and were classified in Tables 3 and 4 and Figure 15.

3.2. Load-Deflection Relationship. Load-deflection curves of specimen $\mathrm{C} 3 \mathrm{~F}$ and $\mathrm{C} 3 \mathrm{H}$ are in Figures 16 and 17. Vertical deflection was only $1.78 \mathrm{~mm}$ before buckling and reached $2.80 \mathrm{~mm}$ after buckling suddenly. It continued to increase 
TABle 2: Properties of tensile test.

\begin{tabular}{lcccccc}
\hline Label & $\begin{array}{c}\text { Yield strength } \\
(\mathrm{MPa})\end{array}$ & $\begin{array}{c}\text { Tensile strength } \\
(\mathrm{MPa})\end{array}$ & $\begin{array}{c}\text { Yielding to } \\
\text { tensile ratio }\end{array}$ & $\begin{array}{c}\text { Elastic modulus } \\
\left(\times 10^{5} \mathrm{MPa}\right)\end{array}$ & \multicolumn{2}{c}{ Poisson ratio } \\
$\mu$
\end{tabular}

TABLE 3: Failure mode classification.

\begin{tabular}{ll}
\hline Mode & Description of failure \\
\hline A & $\begin{array}{l}\text { One fold plate of webs was buckled first. As load increased, the buckling line appeared along } 60^{\circ} \text { at upper left } \\
\text { corner or bottom right corner, resulting in buckling of adjacent fold plate. }\end{array}$ \\
\hline B & $\begin{array}{l}\text { One fold plate of webs close to top flange was buckled first and then it approached to middle stiffener. As load } \\
\text { increased, buckling was developed to flanges longitudinally. Finally the area between flange and webs buckled. }\end{array}$ \\
\hline C & $\begin{array}{l}\text { Web was buckled along the diagonal direction between two adjacent stiffeners and then both sides of the } \\
\text { specimens buckled continuously. }\end{array}$ \\
\hline
\end{tabular}

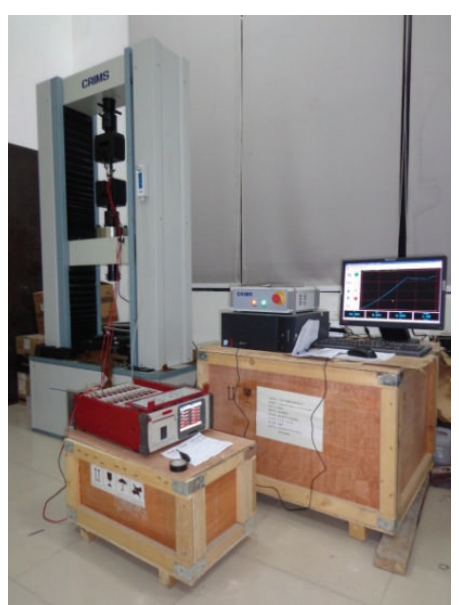

FigURE 11: DDL100 electronic universal testing system.

TABLE 4: Failure modes and shear capacity of specimens.

\begin{tabular}{lcc}
\hline Label & $\begin{array}{c}\text { Shear capacity } \\
V_{\max }\end{array}$ & Failure mode \\
\hline C3F & 296.25 & $\mathrm{~A}$ \\
$\mathrm{C} 3 \mathrm{H}$ & 288.35 & $\mathrm{~A}$ \\
$\mathrm{C} 2 \mathrm{~F}$ & 205.40 & $\mathrm{~B}$ \\
$\mathrm{C} 2 \mathrm{H}$ & 197.50 & $\mathrm{~B}$ \\
P3F & 244.90 & $\mathrm{C}$ \\
\hline
\end{tabular}

until getting close to $7.3 \mathrm{~mm}$ at ultimate load, finally reaching $10 \mathrm{~mm}$ displacement at 0.85 ultimate shear capacities. Figure 17 indicated that the similar load-displacement relations for specimen $\mathrm{C} 3 \mathrm{H}$ with displacement before buckling, after buckling, and at maximum load and final load are equivalent to $2.06 \mathrm{~mm}, 3.36 \mathrm{~mm}, 7.12 \mathrm{~mm}$, and $10 \mathrm{~mm}$, respectively.

Load-deflection curve of specimen P3F is shown in Figure 18. Compared with specimen C3F, load decreases continuously after buckling. Vertical deflection was close up to $8 \mathrm{~mm}$ in the end when loading was stopped at relatively large deflection of top flange.

Figure 19 shows load-deflection curve of specimen C2F. It was observed from test that despite weld filler material dropping continuously at $71.10 \mathrm{kN}$, deflection of the specimens was kept increasing. Deflection increased to about $8 \mathrm{~mm}$ after buckling until the final load which is about $71.2 \%$ of maximum load. In contrary, specimens $\mathrm{C} 2 \mathrm{H}$ showed quite different load-deflection relationship in Figure 20. At $110.6 \mathrm{kN}$, web buckling appeared and specimen deflection increased from $1.68 \mathrm{~mm}$ to $2.68 \mathrm{~mm}$. After that, shear stiffness changes dramatically. When folded plate buckling occurred for all folding plates, load dropped to $51 \%$ of the maximum load suddenly.

3.3. Load-Strain Relationship. Strain gages were installed on the folded plates in the girder specimens. The collected load and strain data were presented in load-microstrain curves for the specimen C2F, which were the typical case for all specimens. As shown in Figure 21, all the folded plate reached yielding strain above $2000 \mu \varepsilon$. It also showed yielding plateau for all tested folding plates presented in Figure 21. These were confirmed by the buckling phenomena observed in the test.

\section{FEM Analysis and Parameters Study}

The effect of parameters on ultimate load capacity was investigated by using finite element analysis. It included web thickness, web height, flange width, and yield strength of steel. 


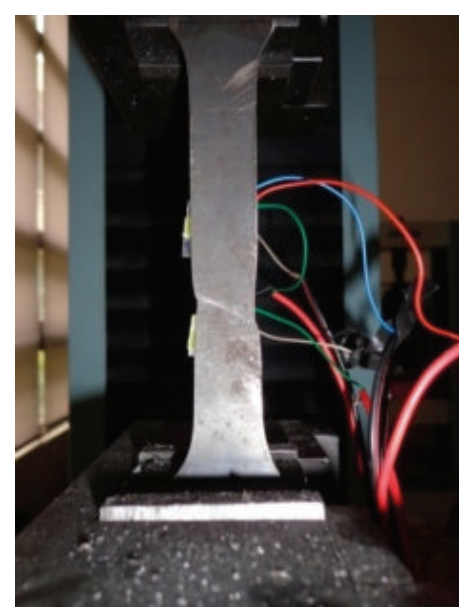

(a) $2 \mathrm{~mm}$ specimen

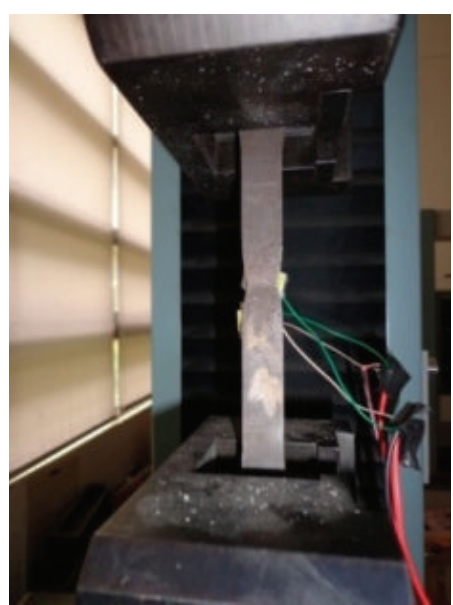

(d) Necking

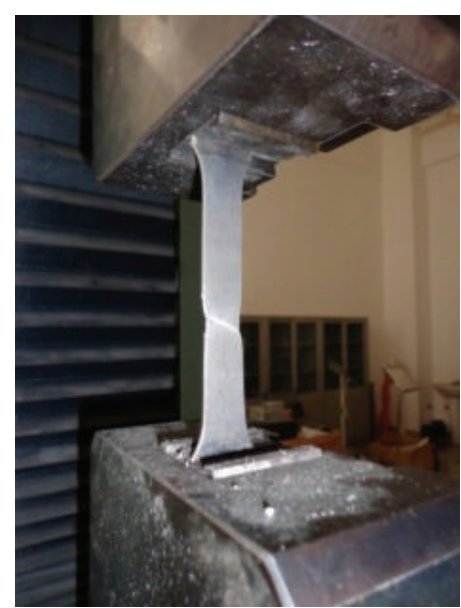

(b) $2 \mathrm{~mm}$ specimen

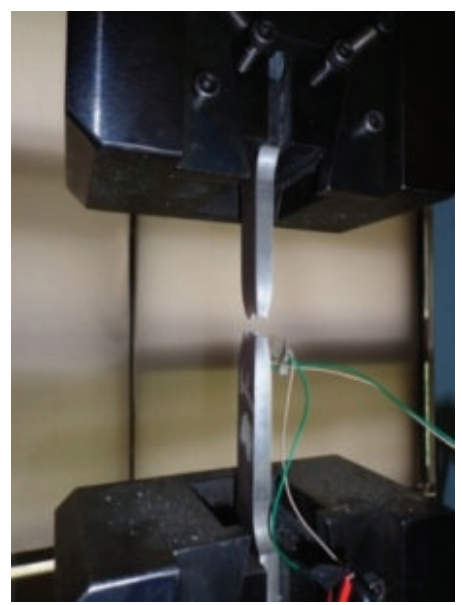

(e) Fracture failure

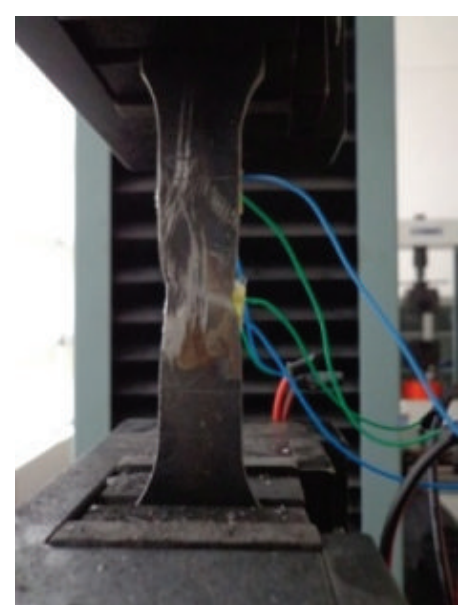

(c) Fracture failure

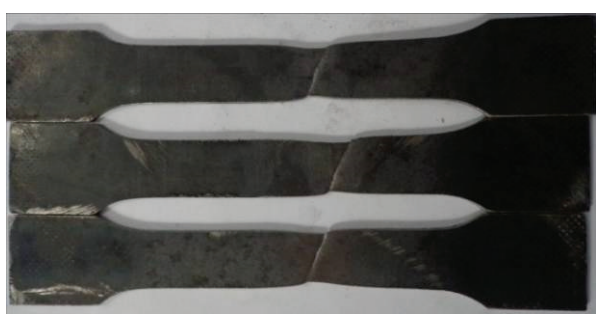

(f) $2 \mathrm{~mm}$ specimen failure mode

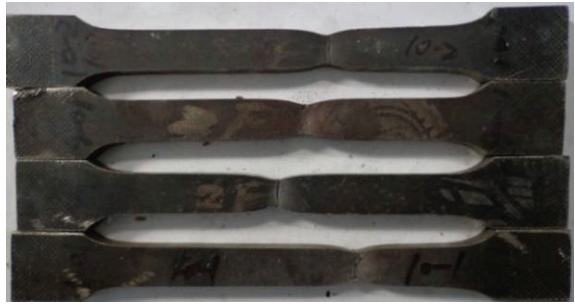

(g) $10 \mathrm{~mm}$ specimen failure mode

FIGURE 12: Failure modes of tensile specimens.
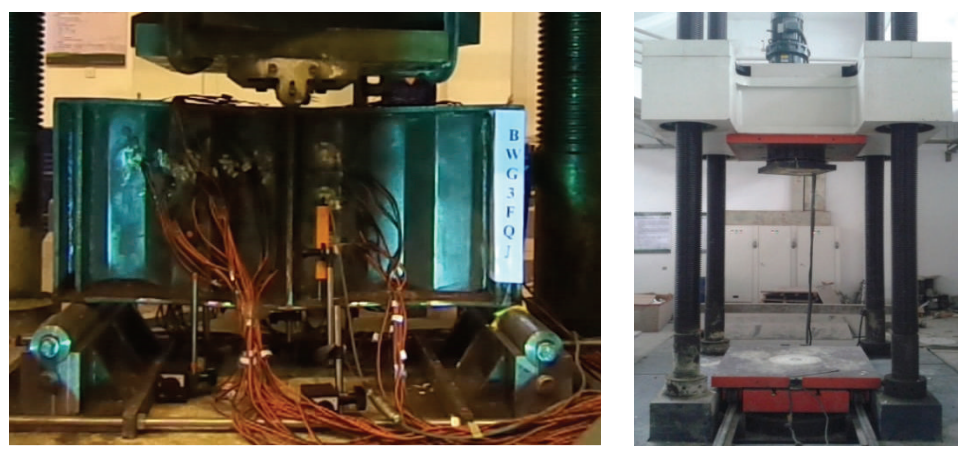

FIgURE 13: Test setup. 


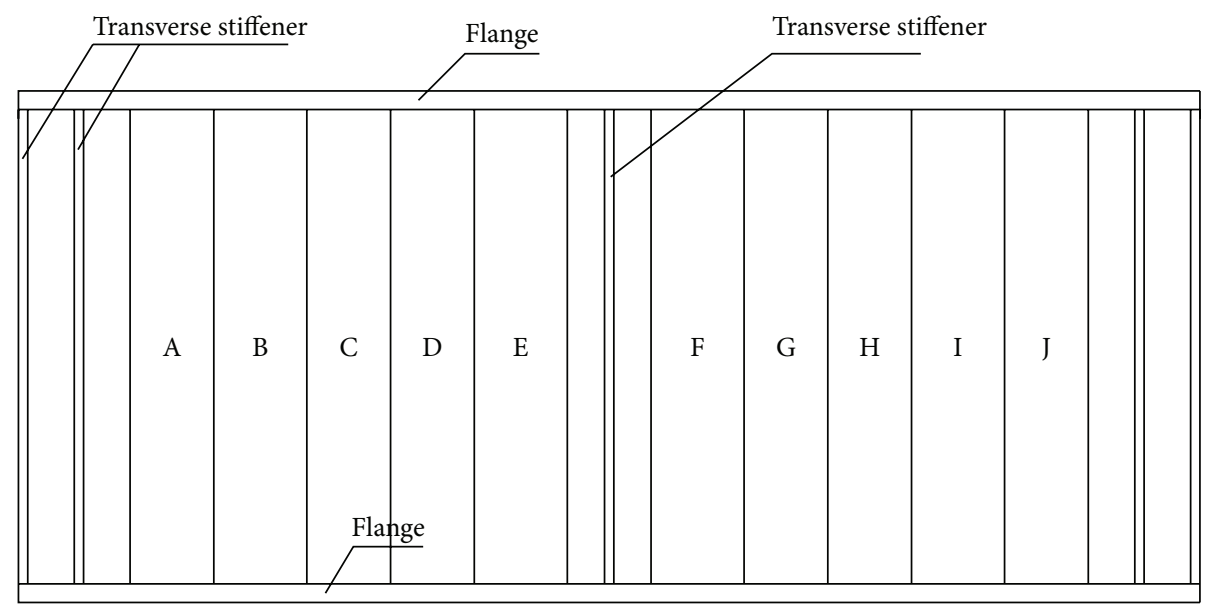

FIgURE 14: Elevation view of the web.

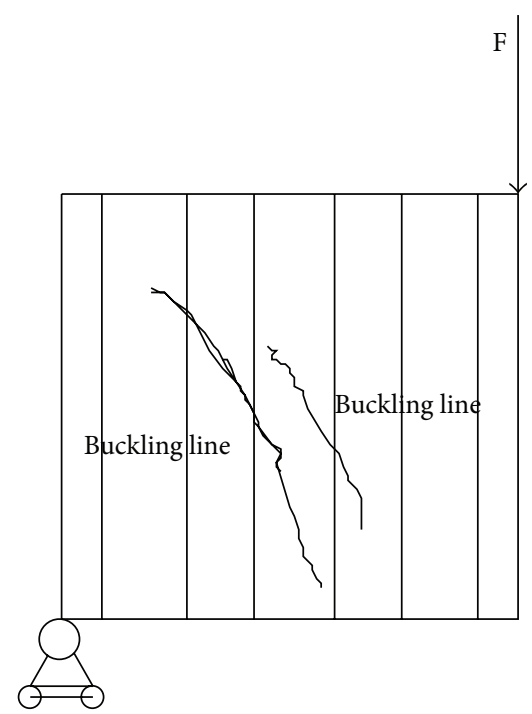

(a) Mode A

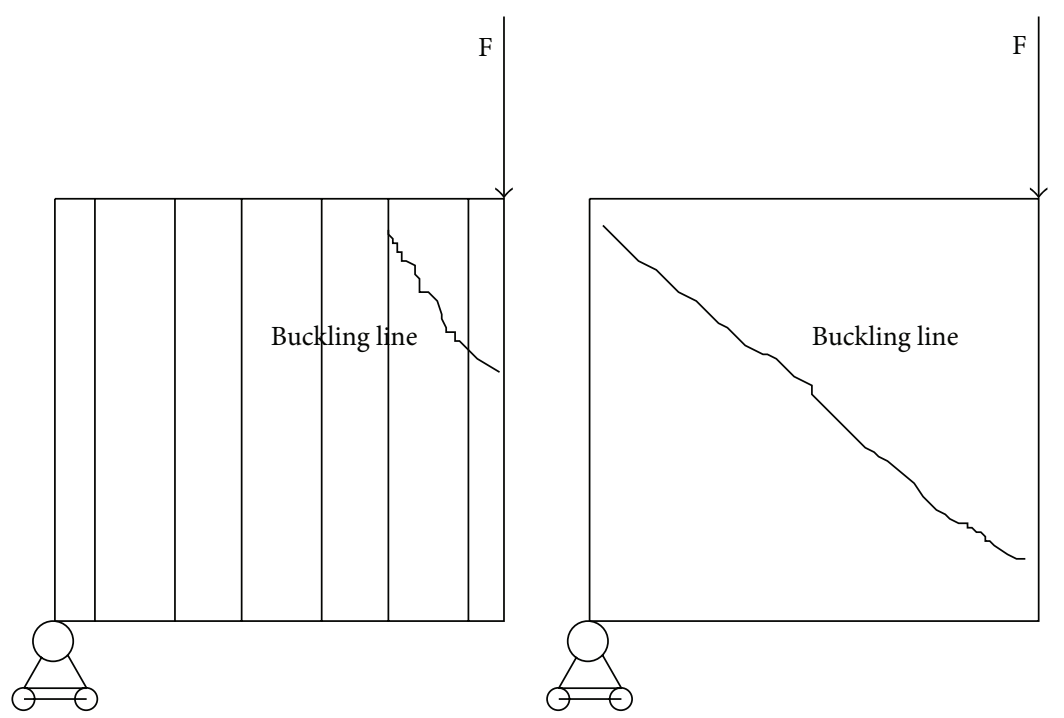

(b) Mode B

(c) Mode C

FIGURE 15: Failure modes.

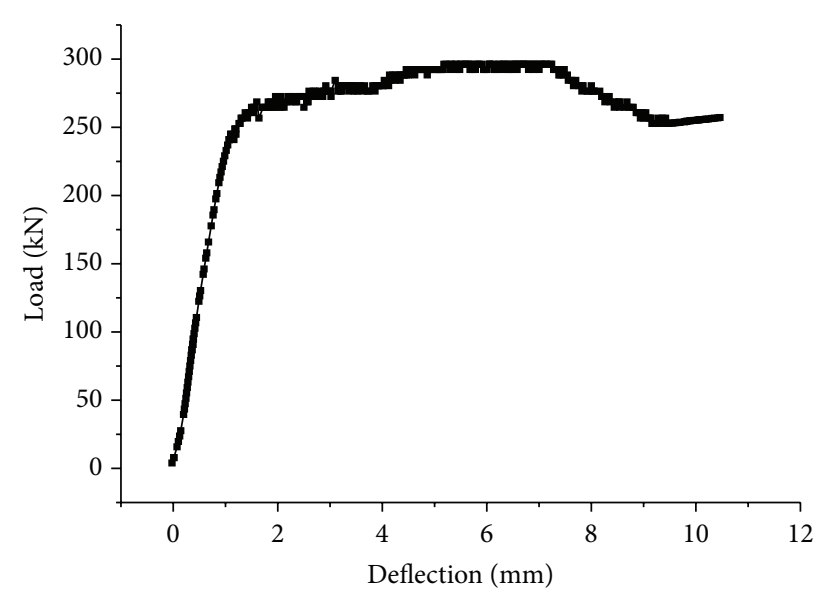

$\rightarrow \mathrm{C} 3 \mathrm{~F}$

Figure 16: Load-deflection curve of C3F.

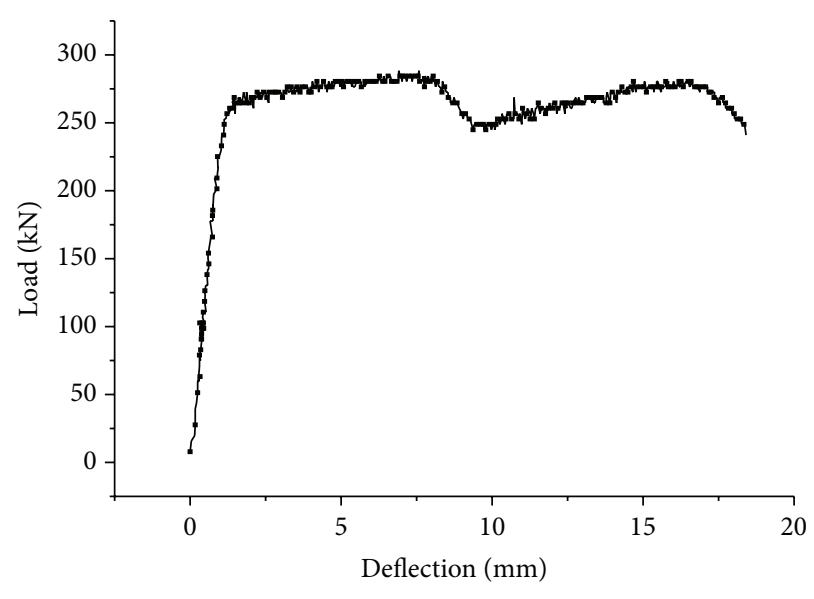

$\rightarrow \mathrm{C} 3 \mathrm{H}$

FIGURE 17: Load-deflection curve of $\mathrm{C} 3 \mathrm{H}$. 
TABLE 5: Effect of web thickness on shear capacity.

\begin{tabular}{lccc}
\hline Label & Thickness $(\mathrm{mm})$ & Elastic modulus $\left(\times 10^{5} \mathrm{MPa}\right)$ & 1.860 \\
C2F & 1.77 & 2.031 & 205.40 \\
$\mathrm{C} 3 \mathrm{~F}$ & 2.50 & 1.860 & 296.25 \\
$\mathrm{C} 2 \mathrm{H}$ & 1.77 & 2.031 & 197.50 \\
$\mathrm{C} 3 \mathrm{H}$ & 2.50 & & 288.35 \\
\hline
\end{tabular}

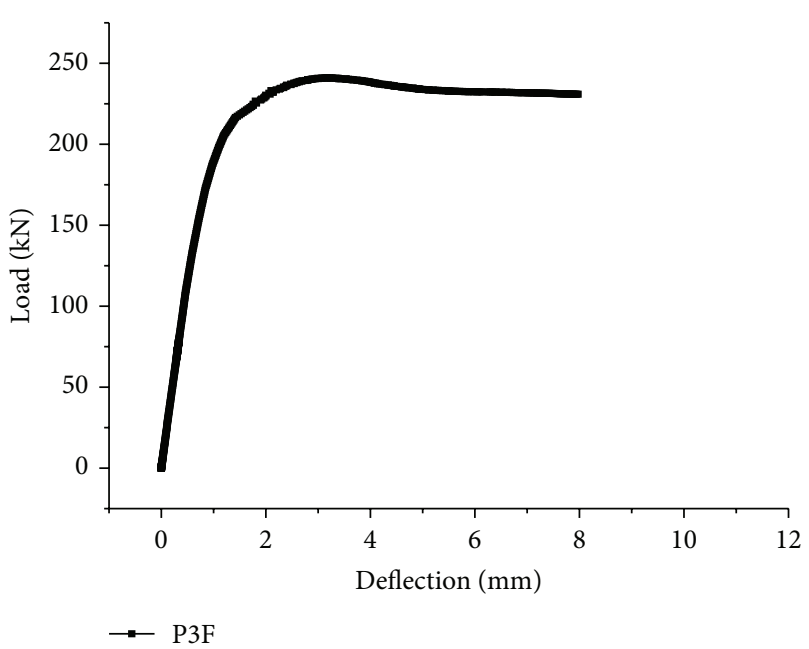

Figure 18: Load-deflection curve of P3F.

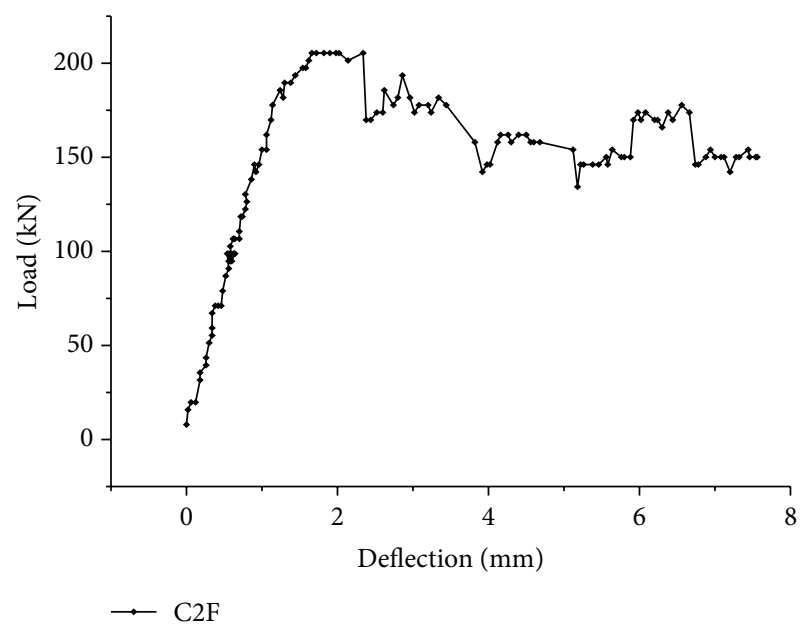

Figure 19: Load-deflection curve of C2F.

4.1. ANSYS Modeling Setup. Geometrical and material nonlinearity were both considered in FEM in structural stability analysis. Triple-line stress-strain relation of steel was adopted in the analysis, and shell element 181 with 4 nodes was used to establish the corrugated web $\mathrm{H}$ shape steel girders as well as plain web weld $\mathrm{H}$ steel girder FEM analysis model.

Finite element model of the specimen is presented in Figure 22. Detailed parameters according to the material test were listed below; for flange and stiffener, modulus of elasticity is $2.059 \times 10^{5} \mathrm{MPa}$, poisson's ratio is 0.27 , yield strength is $303 \mathrm{MPa}$, and tensile strength is $433 \mathrm{MPa}$. For $3 \mathrm{~mm}$ web,

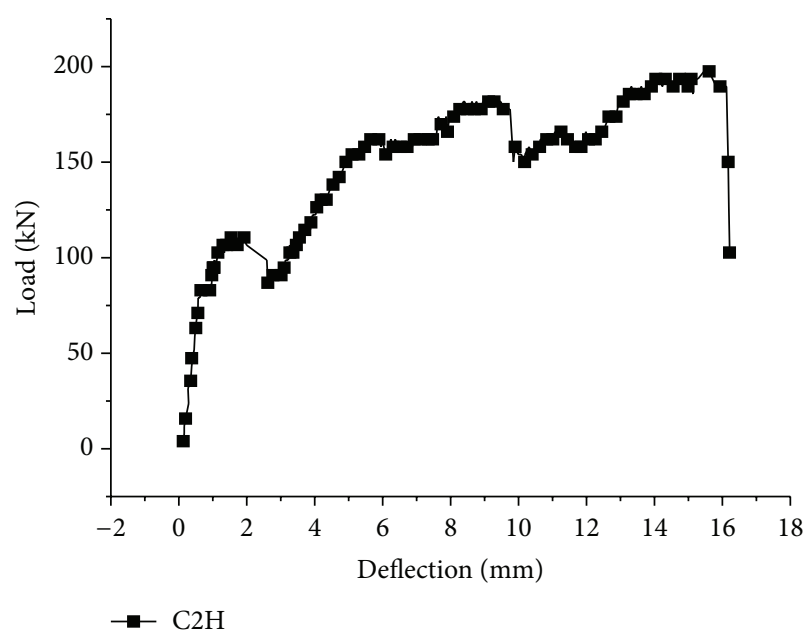

FIgURE 20: Load-deflection curve of $\mathrm{C} 2 \mathrm{H}$.

elastic modulus is $2.031 \times 10^{5} \mathrm{MPa}$, poisson's ratio is 0.24 , yield strength is $342 \mathrm{MPa}$, and tensile strength is $415 \mathrm{MPa}$. For $2 \mathrm{~mm}$ web, elastic modulus is $1.860 \times 10^{5} \mathrm{MPa}$, poisson's ratio is 0.22 , yield strength is $341 \mathrm{MPa}$, and tensile strength is $398 \mathrm{MPa}$.

During the manufacture of the steel girder, residual stress will appear inevitably. Welding simulation of steel girder was carried out by FEM and stresses distribution in web as well as in flange is shown in Figure 23.

4.2. Influence of the Thickness of Corrugated Web. Table 5 shows the tested shear capacity of corrugated web specimens. By comparison, it can be found that, with the increase of web thickness, shear load capacity increases by $44 \%$, and $46 \%$ for full stiffener and half stiffener reinforcement, respectively. It can be also inferred from Table 5 that corrugated web specimens with full stiffener showed higher load capacity than that of half stiffener, as expected. Among all, $3 \mathrm{~mm}$ thick corrugated web specimen with full stiffener reinforcement presented the highest shear capacity. The effect of thickness of corrugated web on load capacity was studied by comparison of FEM results with experimental results at different web thickness. Results were shown in Tables 6 and 7. It can be inferred from Tables 6 and 7 that the FE results matched the experimental values quite well with the maximum error of $3.63 \%$ and minimum error of $0.95 \%$. FEM analysis gave reliable and accurate prediction on the load capacity and load-deflection relation.

Table 8 listed the ratio of load capacity of $3 \mathrm{~mm}$ web specimen to that of $2 \mathrm{~mm}$ web specimen both from experiment and 


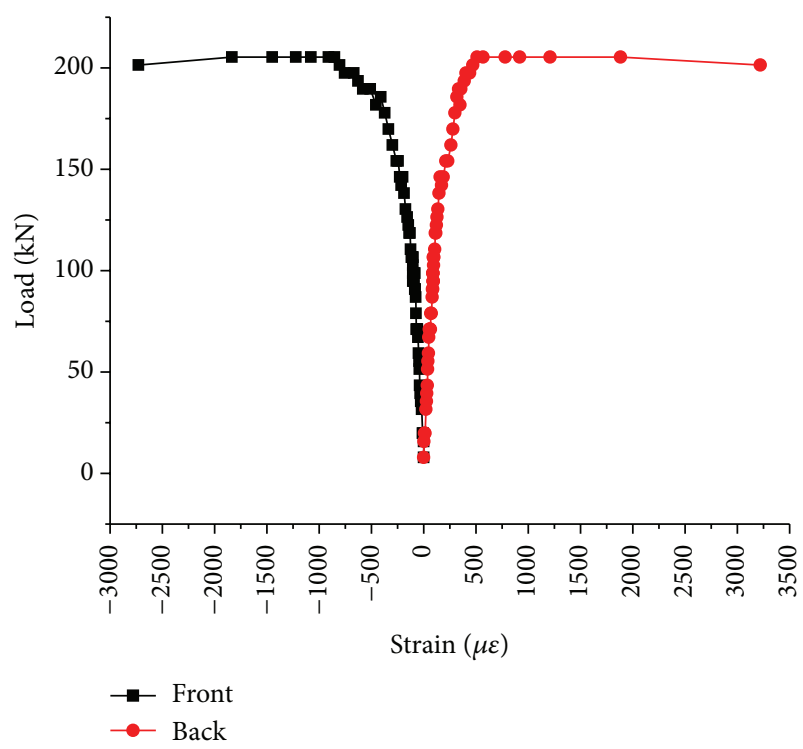

(a) Top of fold plate F

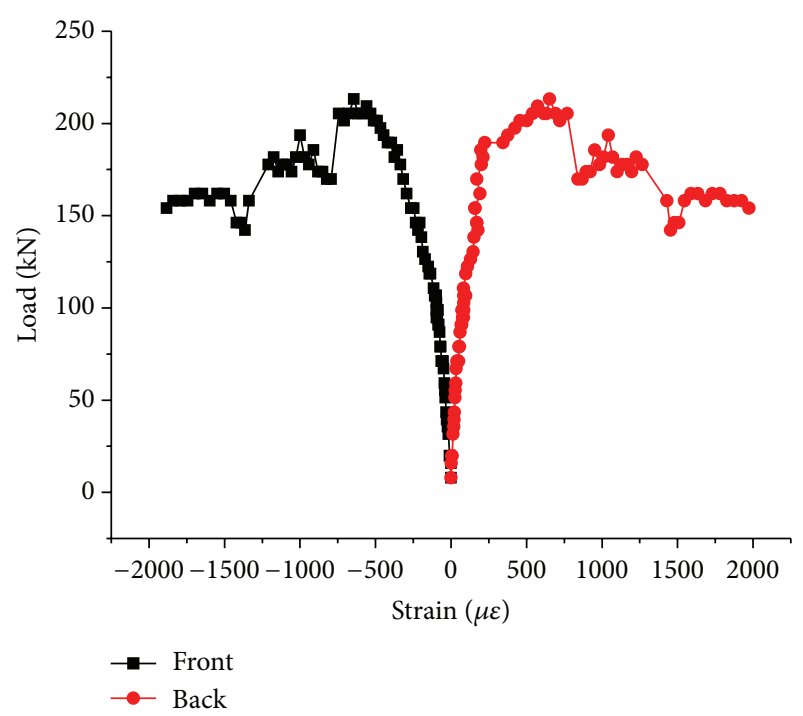

(c) Bottom of fold plate $\mathrm{F}$

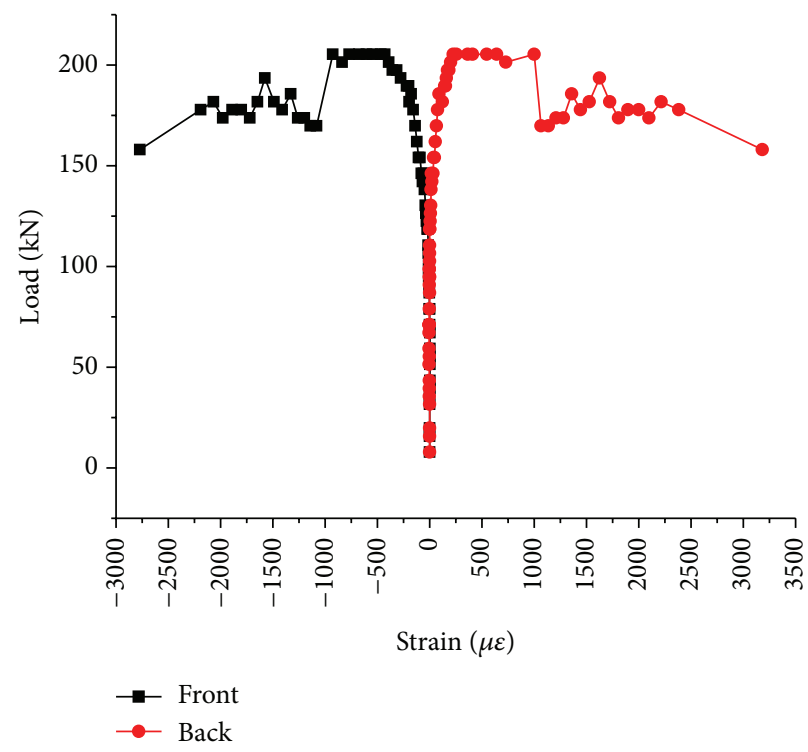

(b) Middle height of fold plate F

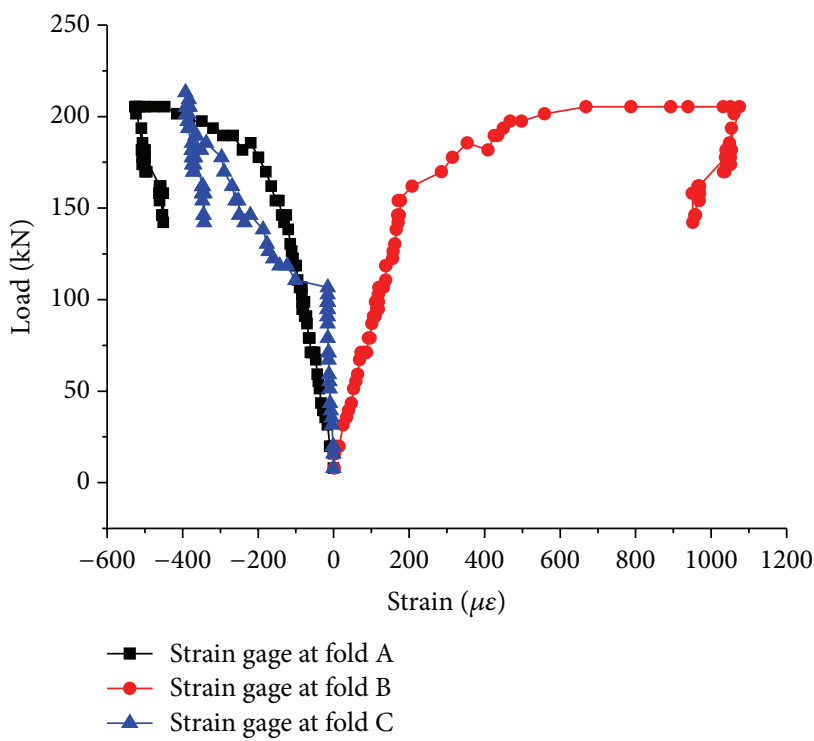

(d) Fold plates A, B, and C

FIgURE 21: Load-strain of specimen C2F (Typical).

TABLE 6: Shear capacity of full stiffener reinforcement specimens.

\begin{tabular}{lcccc}
\hline Specimen & Thickness $(\mathrm{mm})$ & Elastic modulus $\left(\times 10^{5} \mathrm{MPa}\right)$ & Experimental $(\mathrm{kN})$ & FEM $(\mathrm{kN})$ \\
\hline C2F & 1.77 & 1.860 & 205.40 & Error \\
C3F & 2.50 & 2.031 & 296.25 & 3.63 \\
\hline
\end{tabular}

Note: Error $=\mid$ FEM result - Experimental result $\mid /$ Experimental result $\times 100 \%$.

TABLE 7: Shear capacity of half stiffener reinforcement specimens.

\begin{tabular}{lccccc}
\hline Specimen & Thickness $(\mathrm{mm})$ & Elastic modulus $\left(\times 10^{5} \mathrm{MPa}\right)$ & Experimental $(\mathrm{kN})$ & FEM $(\mathrm{kN})$ & Error \\
\hline $\mathrm{C} 2 \mathrm{H}$ & 1.77 & 1.860 & 197.50 & 0.68 \\
$\mathrm{C} 3 \mathrm{H}$ & 2.50 & 2.031 & 288.35 & 196.16 & 280.00 \\
\hline
\end{tabular}

Note: Error $=\mid$ FEM result - Experimental result $\mid /$ Experimental result $\times 100 \%$. 
TABLE 8: Comparison of load capacity at different web thickness.

\begin{tabular}{lccc}
\hline Specimen 1: Specimen 2 & Ratio of web thickness & Ratio of experimental result & Ratio of FEM result \\
\hline $\mathrm{C} 3 \mathrm{~F}: \mathrm{C} 2 \mathrm{~F}$ & 1.41 & 1.44 & 1.48 \\
$\mathrm{C} 3 \mathrm{H}: \mathrm{C} 2 \mathrm{H}$ & 1.41 & 1.46 & 1.43 \\
\hline
\end{tabular}

TABLE 9: Shear capacity of $3 \mathrm{~mm}$ specimen.

\begin{tabular}{|c|c|c|c|c|c|}
\hline Specimen & Wave height (mm) & Fold plate width $(\mathrm{mm})$ & Experimental (kN) & FEM $(\mathrm{kN})$ & Error \\
\hline P3F & - & - & 244.90 & 242.54 & 0.96 \\
\hline $\mathrm{C} 3 \mathrm{H}$ & 40.00 & 66.00 & 288.35 & 280.00 & 2.90 \\
\hline $\mathrm{C} 3 \mathrm{~F}$ & 40.00 & 66.00 & 296.25 & 293.43 & 0.95 \\
\hline
\end{tabular}

Note: Error $=\mid$ FEM result - Experimental result $\mid /$ Experimental result $\times 100 \%$.

TABLE 10: Comparison of shear capacity with and without corrugation.

\begin{tabular}{lccr}
\hline Specimen 1: Specimen 2 & Ratio of web thickness & Ratio of experimental result & Ratio of FEM result \\
\hline C3F : P3F & 1 & 1.210 & 1.209 \\
C3H : P3F & 1 & 1.177 & 1.154 \\
\hline
\end{tabular}

TABLE 11: Shear capacity of $2 \mathrm{~mm}$ specimen under two restraint conditions.

\begin{tabular}{|c|c|c|c|c|}
\hline Specimen & Web thickness $(\mathrm{mm})$ & Experimental $(\mathrm{kN})$ & FEM $(\mathrm{kN})$ & Error \\
\hline $\mathrm{C} 2 \mathrm{~F}$ & 1.77 & 205.40 & 197.95 & $3.63 \%$ \\
\hline $\mathrm{C} 2 \mathrm{H}$ & 1.77 & 197.50 & 196.16 & $0.68 \%$ \\
\hline
\end{tabular}

Note: Error $=\mid$ FEM result - Experimental result $\mid /$ Experimental result $\times 100 \%$.

TABLE 12: Shear capacity of $3 \mathrm{~mm}$ specimen under two restraint conditions.

\begin{tabular}{lcccc}
\hline Specimen & Web thickness $(\mathrm{mm})$ & Experimental $(\mathrm{kN})$ & FEM $(\mathrm{kN})$ & \\
\hline C3F & 2.50 & 296.25 & 293.43 & Error \\
C3H & 2.50 & 288.35 & 280.00 & $2.95 \%$ \\
\hline
\end{tabular}

Note: Error $=\mid$ FEM result - Experimental result $\mid /$ Experimental result $\times 100 \%$.

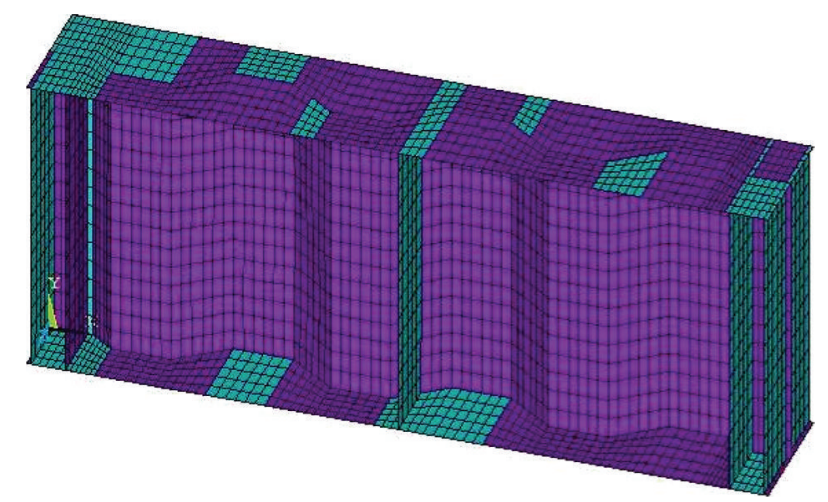

FIgURE 22: Finite element model of specimen.

FEM result. It shows that, under other same conditions, as web thickness increases, the shear capacity increases. Results indicated that as web thickness increases $41 \%$, the shear capacities both from FEM analysis and test increase dramatically with an average of $45 \%$ increase.

4.3. Influence of Corrugation. In order to study the effect of corrugation on the shear capacity, specimens with corrugated web and plain web are compared at the same web thickness. Table 9 listed experimental and analyzed results as well as error. Table 10 presented the comparison of corrugated web specimen with uncorrugated web specimen by giving the ratio of above from test and FEM.

It can be inferred from Tables 9 and 10 that the FE results matched the experimental values quite well with the maximum error of $2.90 \%$ and minimum error of $0.95 \%$. FEM analysis gave reliable and accurate prediction on the load capacity for both corrugated and plain web $\mathrm{H}$ shape steel girder specimens. It also shows that under other same conditions, through corrugation arrangement, the shear capacity increases $19.4 \%$ or so for $3 \mathrm{~mm}$ web thickness specimens.

4.4. Influence of Boundary Conditions. To study the vertical boundary condition effect on the shear load capacity, specimens with full stiffener and half stiffener reinforced were compared both by FEM and experiment under the same conditions. The outcome was shown in Tables 11 and 12. Corresponding ratio of full restraint to half restraint was presented in Table 13 for both FEM analysis and test results.

It can be obtained from Table 13 that, for the same web thickness and same corrugation conditions, the shear capacity of the specimen with full stiffener restraint is higher than 
TABLE 13: Comparison of shear capacity under different restraint.

\begin{tabular}{lcc}
\hline Specimen 1: Specimen 2 & Ratio of experimental results & Ratio of FEM analysis \\
\hline $\mathrm{C} 3 \mathrm{~F}: \mathrm{C} 3 \mathrm{H}$ & 1.03 & 1.05 \\
$\mathrm{C} 2 \mathrm{~F}: \mathrm{C} 2 \mathrm{H}$ & 1.04 & 1.01 \\
\hline
\end{tabular}

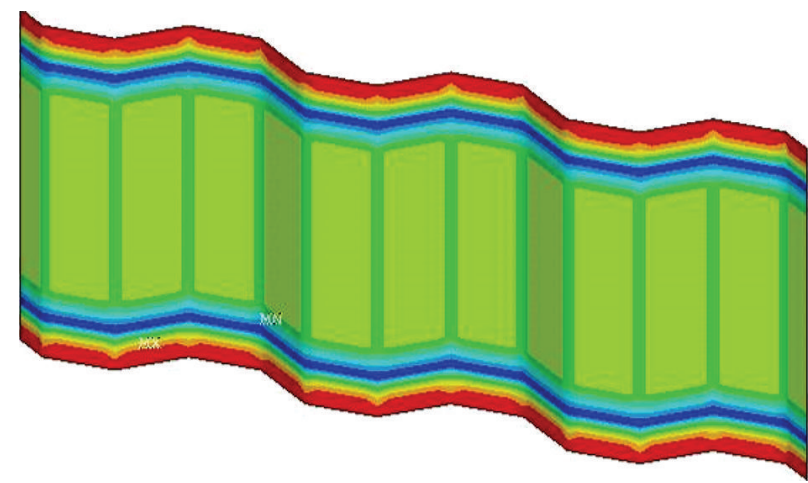

(a) In corrugated webs

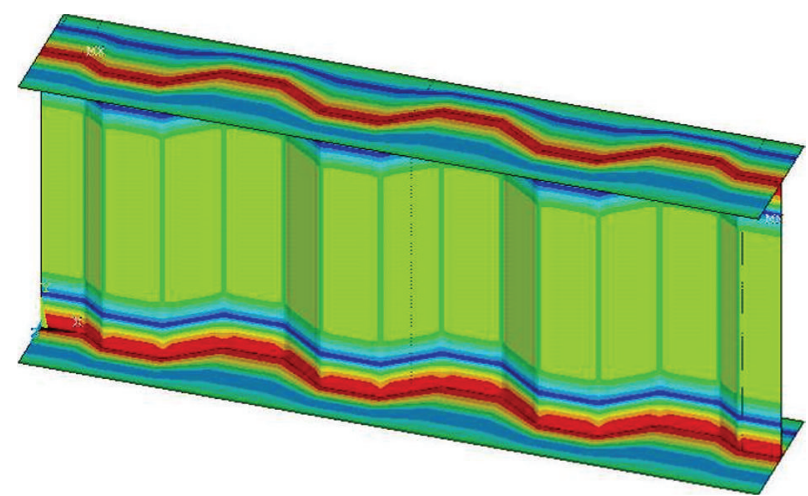

(b) In flanges

FIgURE 23: Residual stresses distribution.

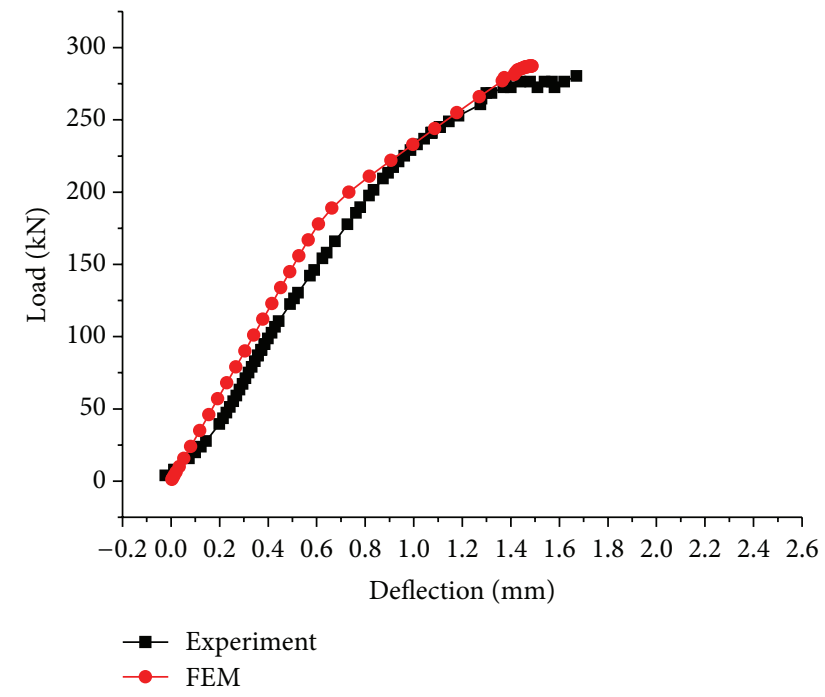

FIgURE 24: Load-deflection curve of C3F.

that of half stiffener restraint. However, the increase is not substantial, only at about $3 \%$ on average.

Figures 24 and 25 presented the load-deflection curves by FEM and experimental results for specimen $\mathrm{C} 3 \mathrm{~F}$ and $\mathrm{C} 3 \mathrm{H}$, respectively. Figures 26 and 27 compared the web deformation from FEM and experiment for specimen $\mathrm{C} 3 \mathrm{~F}$ and $\mathrm{C} 3 \mathrm{H}$. It can be inferred that the good fit between experimental and FEM results for load-deflection relationship is validated from Figures 24 and 25. In the meantime, Figure 27 also validated the failure mode of specimen $\mathrm{C} 3 \mathrm{H}$.

4.5. Parameters Study of Web Thickness in FEM. In previous FEM analysis, the model shown in Figure 22 used web height

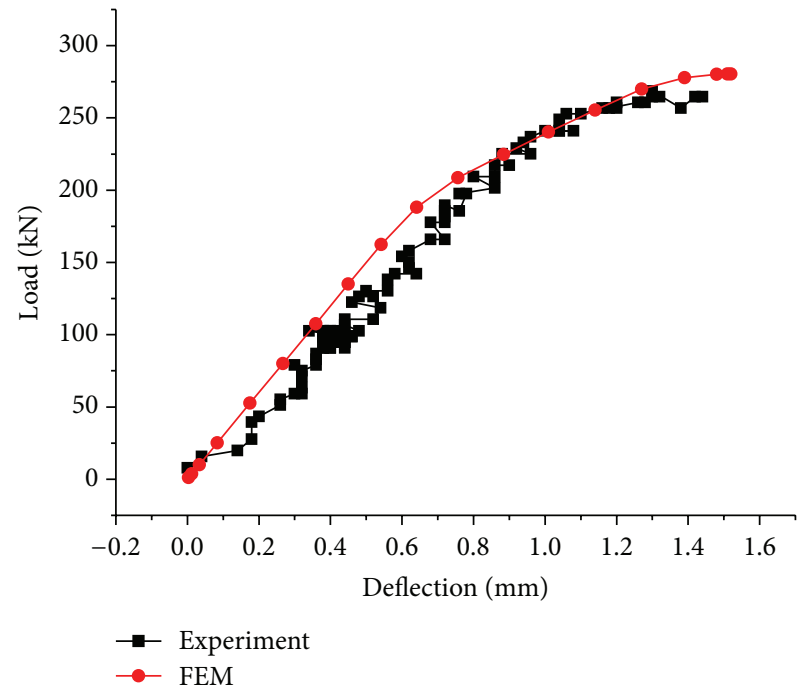

Figure 25: Load-deflection curve of $\mathrm{C} 3 \mathrm{H}$.

of $330 \mathrm{~mm}$, elastic modulus $E=2.05 \times 10^{5} \mathrm{MPa}$, and poisson's ratio $u=0.3$, and the yield stress is $261 \mathrm{MPa}$. Seven models were constructed with different web thickness from 1 to $4 \mathrm{~mm}$ to study the effect of web thickness on load-strain behavior as well as shear capacity. The analytical results are shown in Table 14.

The buckling modes from FEM analysis with web thickness of $3 \mathrm{~mm}$ and $4 \mathrm{~mm}$ were shown in Figure 28. It can be seen from Figure 28 that longitudinal fold plate and the inclined folded plate both buckled as they have the same width and the same slenderness ratio. The buckling orientations are similar as that of the failure mode A that was observed in the experiment. All other six models showed 
TABLE 14: Shear capacity of specimens with variable web thickness.

\begin{tabular}{lccccc}
\hline Number & $t(\mathrm{~mm})$ & $h(\mathrm{~mm})$ & $h / t($ web $)$ & FEM results $(\mathrm{KN})$ & Load ratio \\
\hline 1 & 1.0 & 330 & 330 & 55.49 & 9.271 \\
2 & 1.5 & 330 & 220 & 165 & 0.478 \\
3 & 2.0 & 330 & 132 & 204.71 & 0.617 \\
4 & 2.5 & 330 & 110 & 271.80 & 1.000 \\
5 & 3.0 & 330 & 94.29 & 344.41 & 1.328 \\
6 & 3.5 & 330 & 82.5 & 424.94 & 1.682 \\
7 & 4.0 & 330 & & 2.076 \\
\hline
\end{tabular}

Note: load ratio $=$ individual load value/load value of number 4.
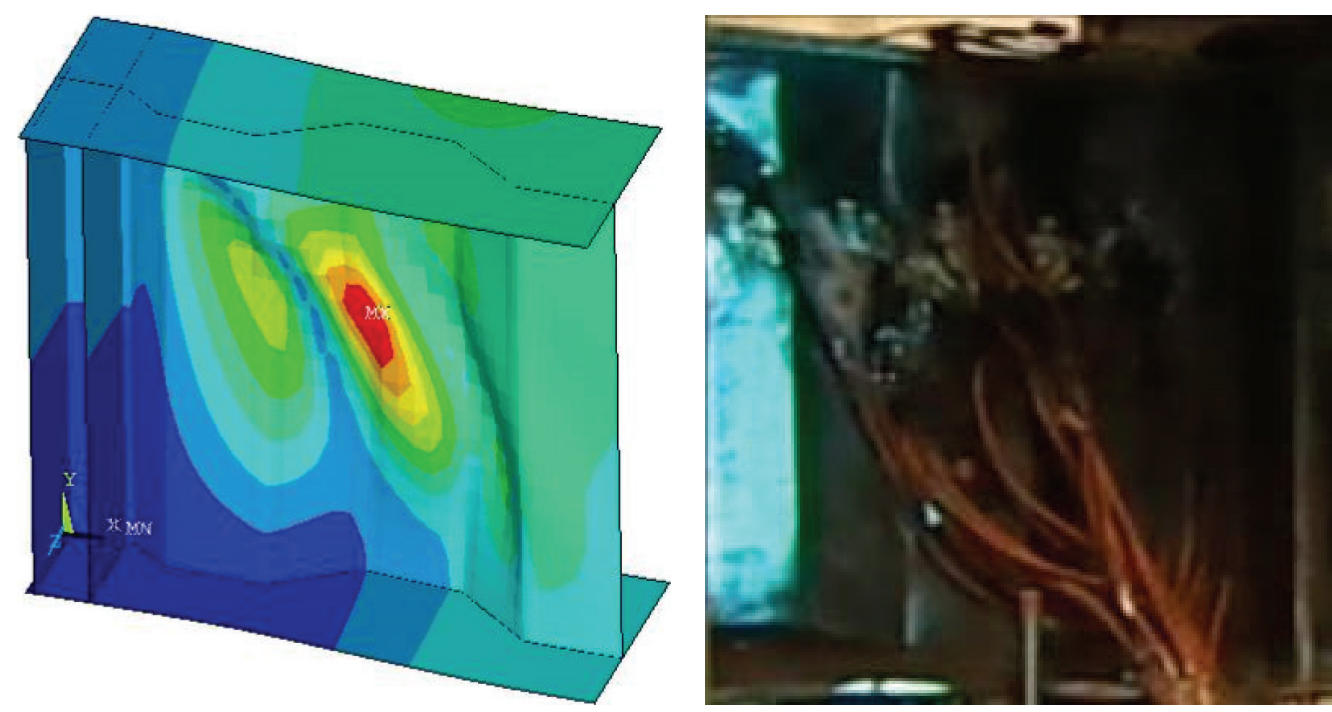

FIGURE 26: Deformation of C3F in FEM and experiment.
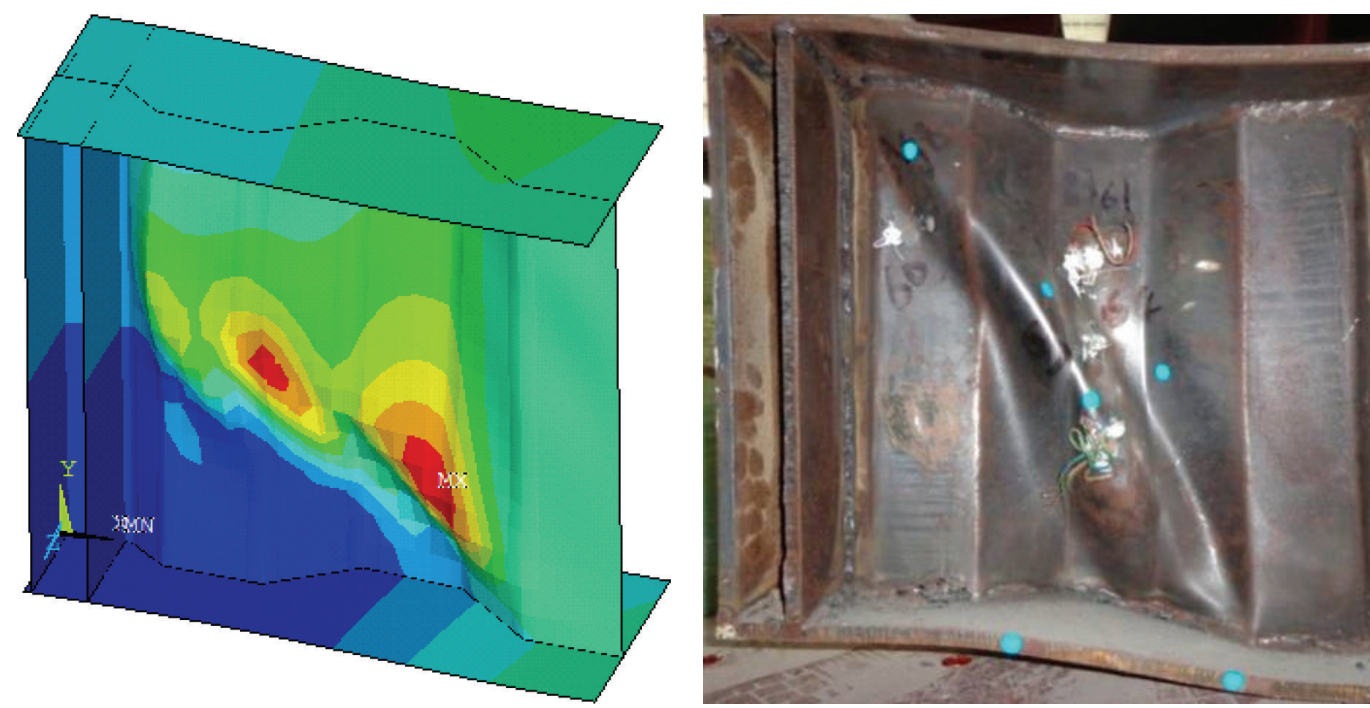

FIGURE 27: Deformation of C3H in FEM and experiment.

the similar buckling mode. Figure 28(b) presented another example of specimen with $4 \mathrm{~mm}$ web thickness.

Figure 29 shows the analytical load-deflection curves for seven different web thicknesses using FEM. It can be seen that as web thickness increases, shear capacity of specimen increases. From Table 14 and Figure 29, it shows that, with the increase of thickness, the shear capacity increases continuously. 


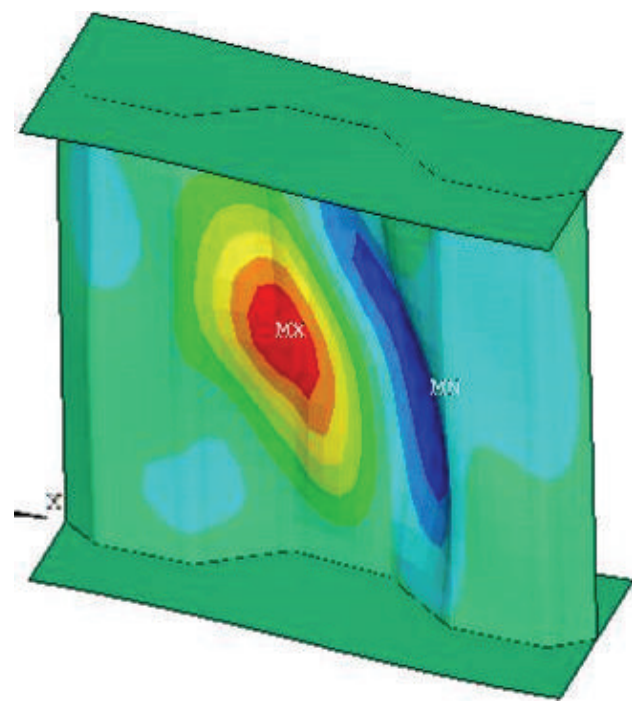

(a) $3 \mathrm{~mm}$ thick web specimen

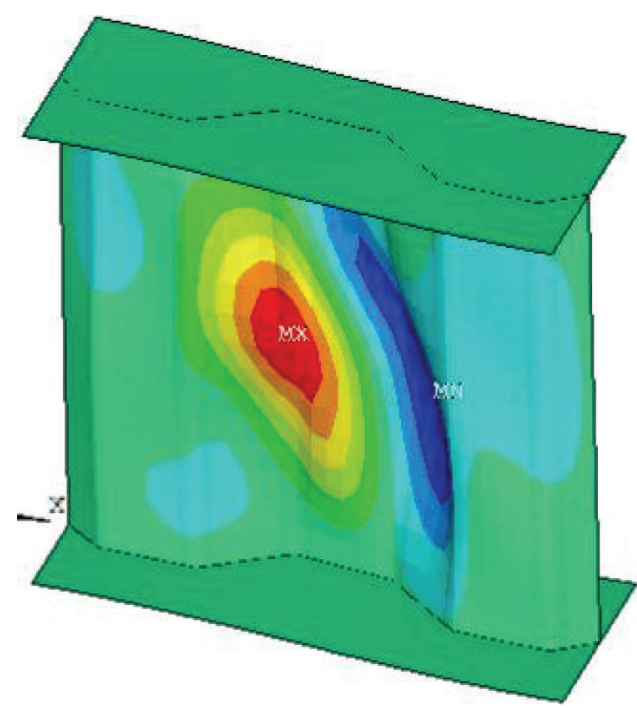

(b) $4 \mathrm{~mm}$ thick web specimen

FIGURE 28: Buckling mode.

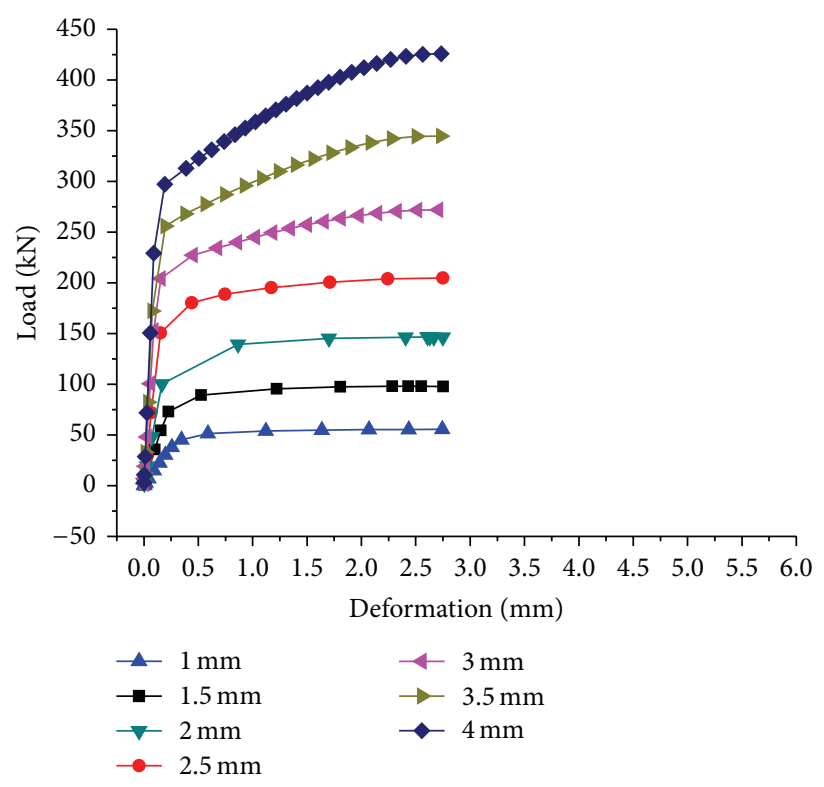

FIGURE 29: Load-deformation curves with variable web thickness.

\section{Conclusions}

Based on the experimental investigation and FEM analysis on corrugated web $\mathrm{H}$ shape steel girder specimens in this study, the following conclusions can be drawn.

(1) Two different buckling modes consisting of local and global buckling were observed in the test.

(2) Results show a good fit between experimental data and finite element analytical results for load-deflection behavior.

(3) Parameters study indicated that as web thickness increases, shear capacity of corrugated web increases significantly at $45 \%$ on average. Among all, $3 \mathrm{~mm}$ thick corrugated web specimen with full stiffener reinforcement presented the highest shear capacity.

(4) It indicated that, under other same conditions, by corrugation arrangement, shear capacity of webs increases $19.4 \%$ or so for $3 \mathrm{~mm}$ web thickness specimens.

(5) It is inferred that, under the same web thickness and corrugation conditions, shear capacities of full stiffener restraint are higher than that of half stiffener restraint condition, at about $3 \%$. 


\section{Conflict of Interests}

The authors declare that there is no conflict of interests regarding the publication of this paper.

\section{Acknowledgments}

The financial support provided by Science and Technology Grant Scheme of Guangdong Transportation Department (2011-02-46) and the National Natural Science Foundation of China (Project no. 51421064 and Project no. 51208077) and The Scientific Research Foundation for the Returned Overseas Chinese Scholars, State Education Ministry (SRF for ROCS, SEM \#47) is gratefully acknowledged.

\section{References}

[1] L. Liu and D. Qian, "Behavior of corrugated steel webs under loading," Journal of the China Railway Society, vol. 22, supplement 1, pp. 53-56, 2000 (Chinese).

[2] S. Li and Y. Guo, "Study on shearing resistance of beams with trapezoidally corrugated webs," Journal of Building Structures, vol. 22, no. 6, pp. 49-54, 2001 (Chinese).

[3] H. Gil, S. Lee, J. Lee, and H. Lee, "Shear buckling strength of trapezoidally corrugated steel webs for bridges," Journal of the Transportation Research Board, vol. 11, no. 1, pp. 473-480, 2005.

[4] H. H. Abbas, R. Sause, and R. G. Driver, "Behavior of corrugated web I-girders under in-plane loads," Journal of Engineering Mechanics, vol. 132, no. 8, pp. 806-814, 2006.

[5] J. Song, H. Ren, and J. Nie, "Nonliear shear buckling analysis of corrugated steel webs," Journal of Highway and Transportation Research and Development, vol. 22, no. 11, pp. 89-92, 2005.

[6] C. Zhou, F. Wang, and Q. Song, "Theoretical analysis and experimental research of corrugated steel web stability," Technology of Highway and Transport, no. 1, pp. 54-57, 2005 (Chinese).

[7] J. Yi, H. Gil, K. Youm, and H. Lee, "Interactive shear buckling behavior of trapezoidally corrugated steel webs," Engineering Structures, vol. 30, no. 6, pp. 1659-1666, 2008.

[8] J. Moon, J.-W. Yi, B. H. Choi, and H.-E. Lee, "Lateral-torsional buckling of I-girder with corrugated webs under uniform bending," Thin-Walled Structures, vol. 47, no. 1, pp. 21-30, 2009.

[9] GB/T 11263, The hot-rolled H and cut T section, 2005 (Chinese). 


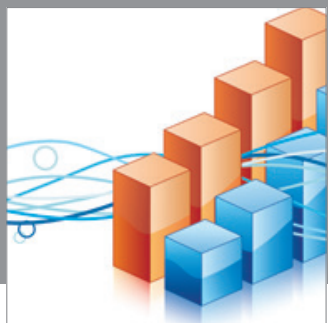

Advances in

Operations Research

mansans

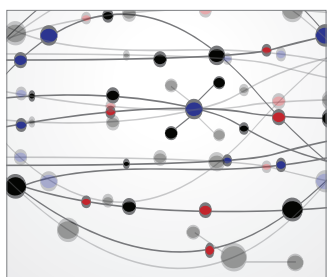

The Scientific World Journal
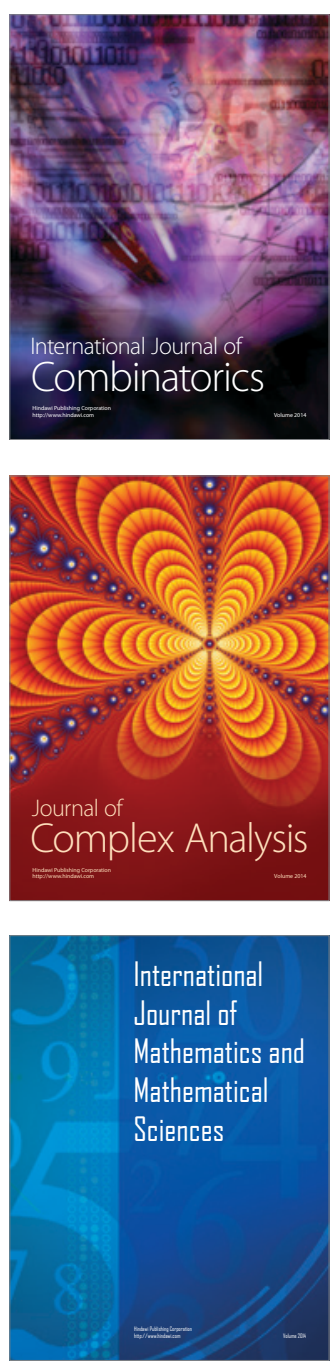
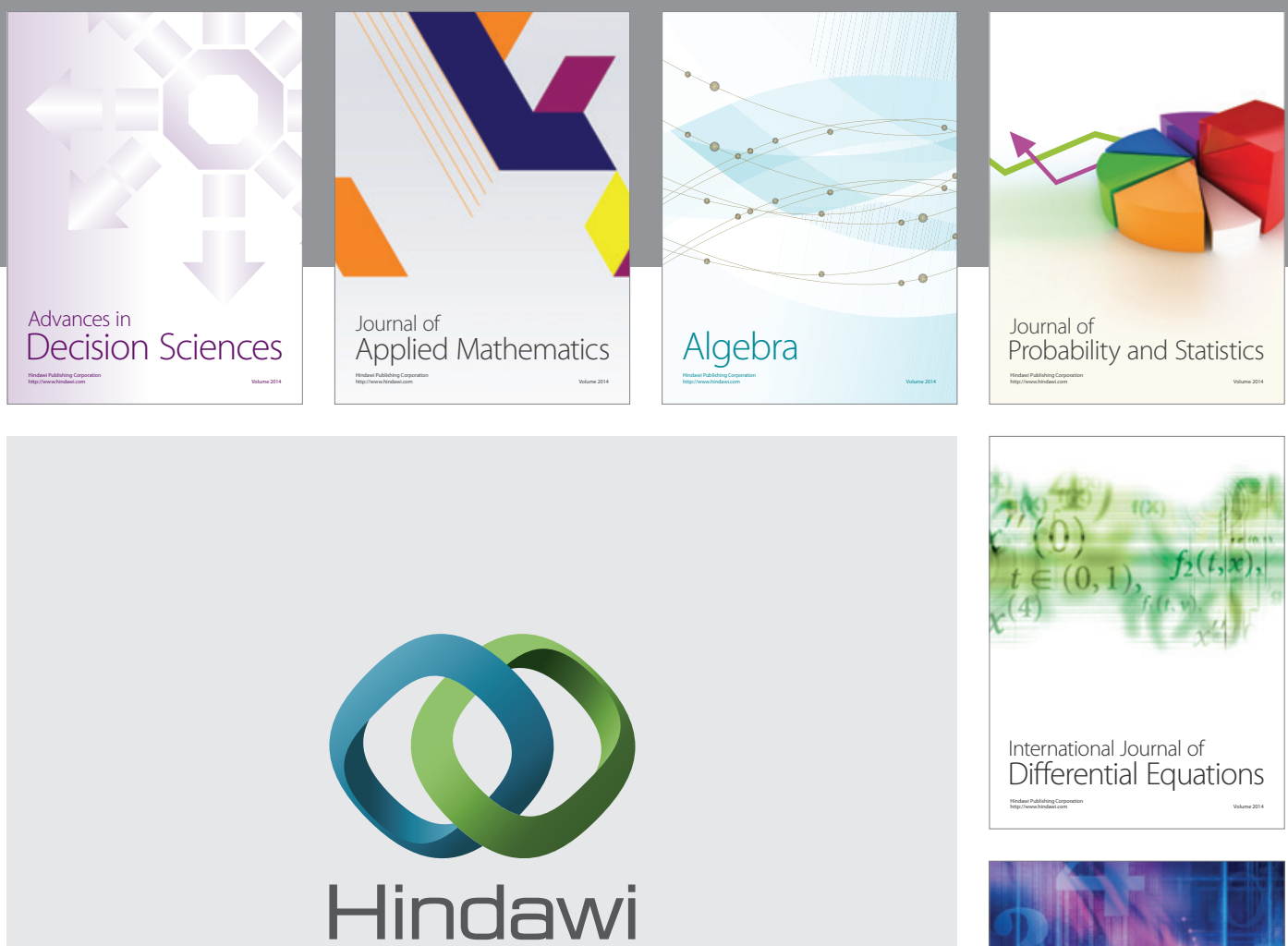

Submit your manuscripts at http://www.hindawi.com
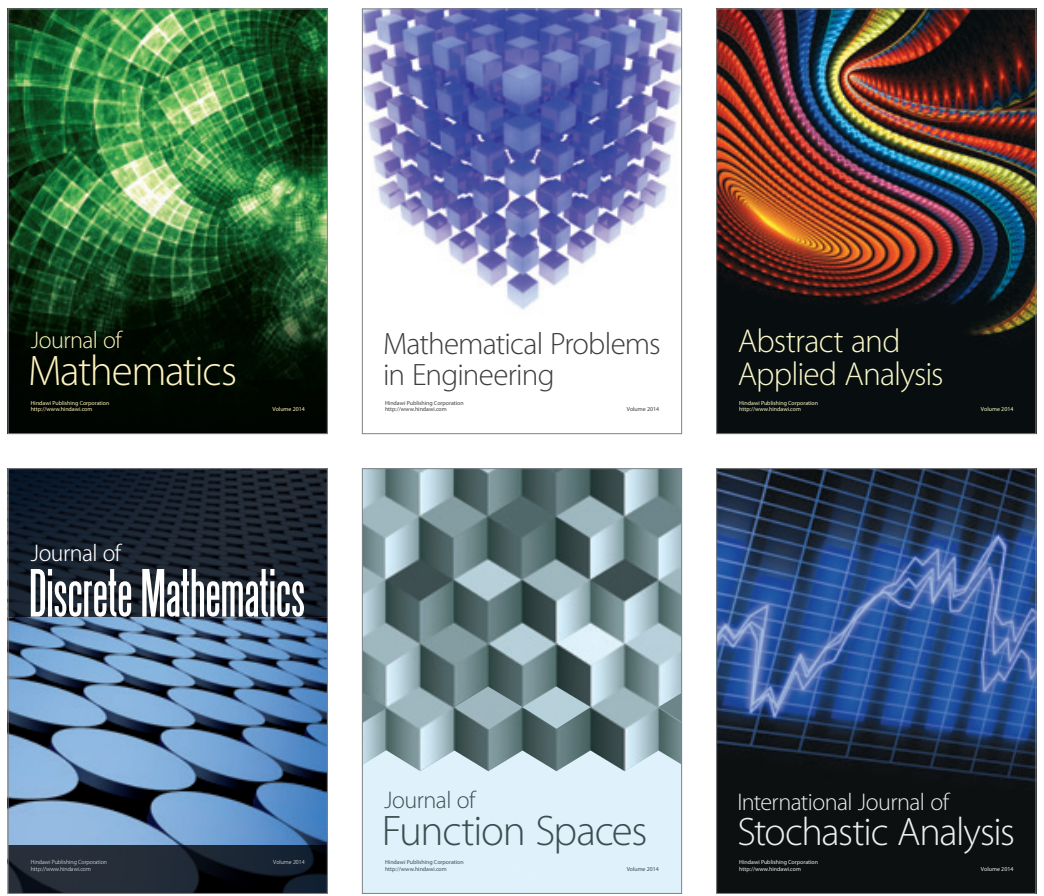

Journal of

Function Spaces

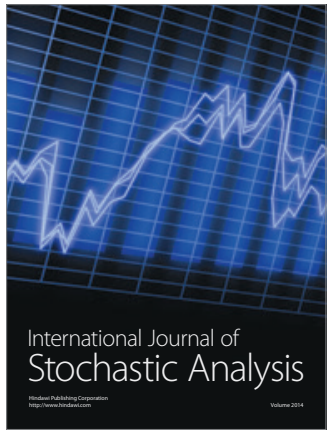

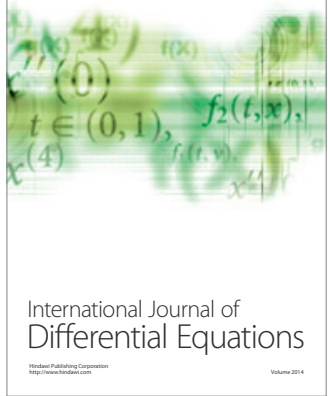
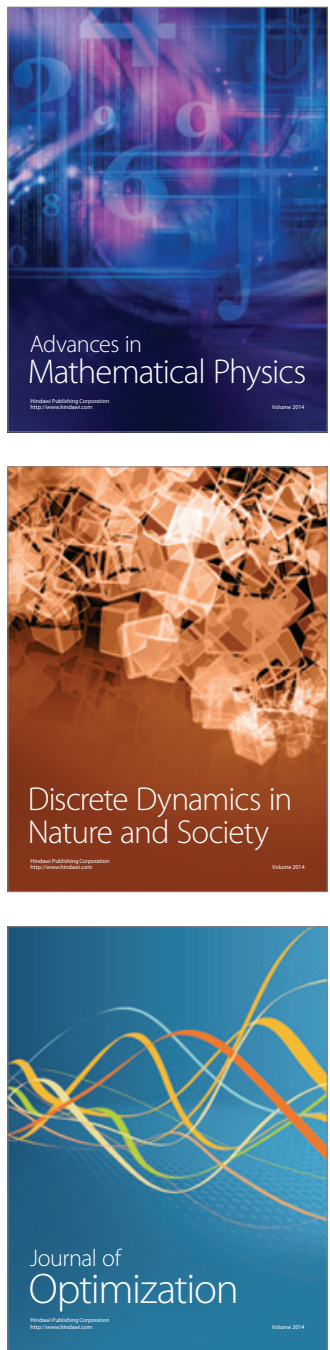